\title{
Update on the Financing of the Fund's Concessional Assistance and Debt Relief to Low-Income Countries
}




\title{
INTERNATIONAL MONETARY FUND
}

\section{IMF POLICY PAPER}

\section{UPDATE ON THE FINANCING OF THE FUND'S CONCESSIONAL ASSISTANCE AND DEBT RELIEF TO LOW-INCOME COUNTRIES}

IMF staff regularly produces papers proposing new IMF policies, exploring options for reform, or reviewing existing IMF policies and operations. The following documents have been released and are included in this package:

- The Staff Report, prepared by IMF staff and completed on April 3, 2018 for the Executive Board's consideration on April 11, 2018.

The IMF's transparency policy allows for the deletion of market-sensitive information and premature disclosure of the authorities' policy intentions in published staff reports and other documents.

\author{
Electronic copies of IMF Policy Papers \\ are available to the public from \\ http://www.imf.org/external/pp/ppindex.aspx \\ International Monetary Fund \\ Washington, D.C.
}




\section{INTERNATIONAL MONETARY FUND}

April 3, 2018

\section{UPDATE ON THE FINANCING OF THE FUND'S}

\section{CONCESSIONAL ASSISTANCE AND DEBT RELIEF TO LOW-INCOME COUNTRIES}

\section{EXECUTIVE SUMMARY}

The Fund is adapting its framework for providing support to low-income countries (LICs) amid rising vulnerabilities. Despite a global economic upswing, many LICS continue to face difficult fiscal and external positions, aggravated by increasing debt levels and natural disasters in many countries. In this context, the Executive Board approved in May 2017 higher annual access limits under the Rapid Credit Facility (RCF) for balance of payment needs arising from large natural disasters and in May 2017 decided to keep the list of Poverty Reduction and Growth Trust (PRGT)-eligible countries unchanged notwithstanding rising per capita income levels. A comprehensive review of PRGT facilities is underway to consider potential adaptations of program modalities and access policies.

PRGT demand in $\mathbf{2 0 1 7}$ was above the historical average for the third year in a row. New commitments totaled SDR 1.7 billion, the highest level since the global financial crisis. Demand is expected to moderate somewhat in 2018. Longer-term demand estimates are broadly unchanged from last year's update, and remain generally consistent with the self-sustaining PRGT financing framework adopted in 2012.

Loan resources have been successfully replenished, while subsidy contributions remain somewhat below pledged amounts. The 2015 fundraising round mobilized slightly more than the initial target of SDR 11 billion in new loan resources from 15 PRGT lenders, which should provide adequate loan resources into the next decade. By contrast, progress has been limited in collecting the remaining pledged resources for subsidizing the interest on PRGT credit.

The PRGT self-sustained capacity remains intact. The PRGT's self-sustained long-term average annual lending capacity is estimated at SDR 1.31 billion, broadly unchanged from last year' estimate. While capacity estimates are sensitive to a variety of factors, they remain relatively close to the target of SDR $1 \frac{1}{4}$ billion under a number of shocks.

The Catastrophe Containment and Relief Trust (CCR Trust) remains underfunded. Funding is below the original targeted amount of new bilateral contributions totaling 
US\$150 million, and the gap is more sizeable when considering the increase of members' quotas under the $14^{\text {th }}$ General Review of Quotas. To meet funding needs for future qualifying catastrophe relief, it is important that countries with outstanding pledges fulfill their commitments and for additional countries to come forward.

Additional financing would be required to provide debt relief to members with protracted arrears. Debt relief under the Heavily Indebted Poor Counties (HIPC) Initiative is winding up, with only two potentially eligible countries left with outstanding Fund credit. These are the protracted arrears cases of Somalia and Sudan. Additional resources would be required to finance the Fund's participation in debt relief when these countries are ready to undertake the HIPC Initiative process. 
Approved By Andrew Tweedie
Prepared by the Finance Department in consultation with the Strategy, Policy and Review and Legal Departments. The staff team was led by Sandra Marcelino and Marta Spinella, and comprised of Ali Al-Sadiq, Constance De Soyres, Christopher Faircloth, Gilda Fernandez, Ivetta Hakobyan, Izabela Rutkowska, and Randa Sab; production assistance by Shanika Jayakody and Amy Miranda (all FIN). Overall guidance was provided by Christian Mumssen and Olaf Unteroberdoerster.

\section{CONTENTS}

Glossary

INTRODUCTION

THE PRGT: SUPPORTING LICS AMID RISING VULNERABILITIES

DEMAND FOR PRGT CONCESSIONAL LENDING $\underline{9}$

SOURCES OF FINANCING FOR THE PRGT $\underline{12}$

$\begin{array}{ll}\text { A. Loan Accounts___ } & \frac{13}{14} \\ \text { B. Subsidy Accounts__ } & \frac{14}{16} \\ \text { C. Reserve Account_— } & \underline{-}\end{array}$

PRGT CAPACITY: ASSESSING ADEQUACY AND SELF-SUSTAINABILITY $\underline{16}$

FINANCING DEBT RELIEF $\underline{20}$

A. Catastrophe Containment and Relief Trust____ $\underline{20}$

B. Highly Indebted Poor Countries Initiative ____ 21

C. Protracted Arrears Cases ______ 21

\section{BOXES}

1. Financial Risks to the PRGT and Lending Safeguards

2. Three-Pillar Strategy of the Self-Sustaining PRGT Financing Framework $\underline{18}$

\section{FIGURES}

1. New PRGT Commitments $\underline{10}$

2. Annual Disbursements to PRGT-Eligible Countries ___

3. PRGT Concessional Financing Framework____ 12

4. PRGT Subsidy Fund-Raising Campaigns ____

5. PRGT Reserve Coverage _____ 16

6. Self-Sustained Capacity and Reserve Account Coverage Under Peak Demand___ 18 


\section{TABLES}

1. New PRGT Commitments in 2017 ______ $\underline{9}$

2. Projected Demand for PRGT Resources Under Alternative Scenarios ___

3. New PRGT Loan Agreements____ $\frac{14}{14}$

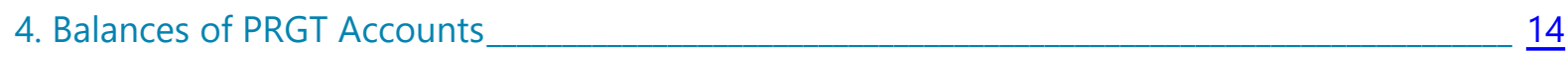

5. Sensitivity of Self-Sustained Capacity ___________

6. Pending Disbursements to Finance Debt Relief to Liberia____ 21 


\section{Glossary}

$\begin{array}{ll}\text { CCR Trust } & \text { Catastrophe Containment and Relief Trust } \\ \text { DSA } & \text { Debt Sustainability Analysis } \\ \text { ECF } & \text { Extended Credit Facility } \\ \text { ESF } & \text { Exogenous Shock Facility } \\ \text { GLA } & \text { General Loan Account } \\ \text { GRA } & \text { General Resources Account } \\ \text { GSA } & \text { General Subsidy Account } \\ \text { HIPC } & \text { Heavily Indebted Poor Countries } \\ \text { IMF } & \text { International Monetary Fund } \\ \text { LICs } & \text { Low Income Countries } \\ \text { MDRI } & \text { Multilateral Debt Relief Initiative } \\ \text { NPA } & \text { Note Purchase Agreement } \\ \text { NPV } & \text { Net Present Value } \\ \text { PCDR } & \text { Post Catastrophe Disaster Relief Trust } \\ \text { PRG-HIPC } & \text { Trust for Special Poverty Reduction and Growth Operations for the Heavily Indebted } \\ & \text { Poor Countries and Interim ECF Subsidy Operations } \\ \text { PRGT } & \text { Poverty Reduction and Growth Trust } \\ \text { RCF } & \text { Rapid Credit Facility } \\ \text { RFI } & \text { Rapid Financing Instrument } \\ \text { SAF } & \text { Structural Adjustment Facility } \\ \text { SCA-1 } & \text { First Special Contingent Account } \\ \text { SCF } & \text { Standby Credit Facility } \\ \text { SDR } & \text { Special Drawing Rights } \\ \text { SLA } & \text { Special Loan Accounts } \\ & \end{array}$




\section{INTRODUCTION}

1. This paper reviews recent developments in the financing of the Fund's concessional lending and debt relief operations since the last update in April 2017. It reports the latest available data on pledges and contributions to the Poverty Reduction and Growth Trust (PRGT) subsidy and loan accounts, including an update on the recent loan mobilization round and the related increase in the PRGT borrowing limit. ${ }^{1}$ The paper also informs the stocktaking and identification of options in the context of the 2018 Review of Facilities for Low-Income Countries (LICS).

2. The paper is organized as follows. The first section presents recent developments of the Fund's concessional lending instruments and the associated financing framework in the context of the current global environment. The following section describes recent PRGT loan commitments and disbursements and updates staff's longer-term demand projections. The paper then examines PRGT resources, updating on efforts to mobilize loan and subsidy contributions. Consistent with the three-pillar strategy, the next section reports on estimates and the robustness of the self-sustained lending capacity under different scenarios. The last section highlights the shortfall of resources for the financing of debt relief under the Catastrophe Containment and Relief Trust (CCR Trust) and provides an update on arrears monitoring, clearance, and debt relief to Somalia and Sudan. The paper concludes with a proposed decision completing the annual review of the financing of the Trust's concessional assistance and debt relief to LICs. ${ }^{3}$

\section{THE PRGT: SUPPORTING LICS AMID RISING VULNERABILITIES}

Key messages:

- Despite a global economic upswing, many LICs continue to face difficult fiscal and external positions, aggravated by shocks and rising debt levels.

- In light of these vulnerabilities, no LIC was removed from the list of PRGT-eligible countries during the 2017 review, and the Executive Board approved higher annual access limits under the Rapid Credit Facility (RCF).

- While providing the needed support to member countries, it is important to safeguard scarce financing resources amid growing risks.

3. Despite a global upswing, many LICs continue to face economic imbalances and a challenging outlook. Growth prospects for LICs are generally improving, supported by a

\footnotetext{
${ }^{1}$ See Modifying the Poverty Reduction Growth Trust (PRGT) Cumulative Borrowing Limit

${ }^{3}$ The decisions adopting both the PRG-HIPC Trust and MDRI Trust Instruments require that the Executive Board conducts annual reviews of the financing of these Trusts (Decision No. 11436-(97/10), ; Decision No. 13588-(05/99); and Decision No. 15765-(15/39)).
} 
strengthening global recovery. However, this more favorable outlook is subject to a range of risks, potentially including a reversal of the recovery in commodity prices, an unexpectedly sharp tightening of global financial conditions, domestic policy slippages, internal conflict, weather shocks, and financial sector stress. Moreover, there has been a broad-based weakening of fiscal positions in LICs in recent years. Total public debt and debt service have continued to rise, with almost half of PRGT-eligible countries now at high risk of debt distress or in debt distress, and one-third at "moderate" risk. Policy challenges are further exacerbated for those LICs that continue to experience conflict and security disruptions or are increasingly hit by severe weather events such as the recent drought-related food shortages in parts of sub-Saharan Africa or hurricanes in the Caribbean.

\section{Against a backdrop of rising vulnerabilities, the Fund's framework for concessional} assistance has continued to adapt to better support eligible members. With the view of enhancing the financial safety net for developing countries, the Executive Board approved in May 2017 the establishment of a large natural disaster window within the RCF and Rapid Financing Instrument (RFI) ${ }^{4}$, with a new annual access limit of 60 percent of quota for urgent balance of payments needs arising from large natural disasters. ${ }^{5}$ In the most recent biennial PRGT eligibility review, the Board assessed the current eligibility framework to ensure it remains appropriate, and agreed to keep the list of PRGT-eligible countries unchanged, as those countries meeting the income and/or market access graduation criteria ${ }^{6}$ were assessed to be facing serious short-term vulnerabilities. ${ }^{7}$ In addition, a comprehensive review of the concessional facilities is expected to be completed this year to ensure continued adequate financial support to LICs.

\section{Growing financial risks from rising debt vulnerabilities highlight the need for} maintaining adequate lending standards (Box 1). The share of PRGT credit to countries at high risk of debt distress or in debt distress has risen to about 30 percent, the highest level since the global financial crisis. While it may increase further based on programs in the pipeline and the recent downgrades of Debt Sustainability Analysis (DSA) risks ratings of potentially large borrowers, lending safeguards under the Fund's multilayered risks management framework will play an important role in mitigating financial risks for the PRGT.

\footnotetext{
${ }^{4}$ See Large Natural Disasters-Enhancing the Financial Safety Net for Developing Countries and Decision No. 16182-(17/35).

${ }^{5}$ A natural disaster, for this purpose, is considered "large" if it caused damage assessed to be equivalent to or to exceed 20 percent of the relevant member's gross domestic product (GDP).

${ }^{6}$ Under the current framework, members without serious short-term vulnerabilities that meet the income and/or market access criteria may graduate from the PRGT list. However, countries with serious short-term vulnerabilities may still graduate if their income level is at least 50 percent higher than the applicable income graduation threshold. See Eligibility to Use the Fund's Facilities for Concessional Financing.

${ }^{7}$ See Eligibility to Use the Fund's Facilities for Concessional Financing.
} 


\section{Box 1. Financial Risks to the PRGT and Lending Safeguards}

PRGT country debt burdens and vulnerabilities have increased sharply in recent years. The fallout from the 2014 commodity price shock alongside delayed corrective policies have contributed to rising debt burdens in many LICs. ${ }^{1 /}$ This is reflected in the marked deterioration in debt distress risk ratings among PRGT-eligible countries. The proportion of PRGT countries either at high risk of debt distress or in debt distress has nearly doubled since 2013 , increasing from 25 percent to 45 percent at end 2017. At the same time, the demand for PRGT resources has increased sharply to average about SDR 1.3 billion during 2014-17, some 30 percent

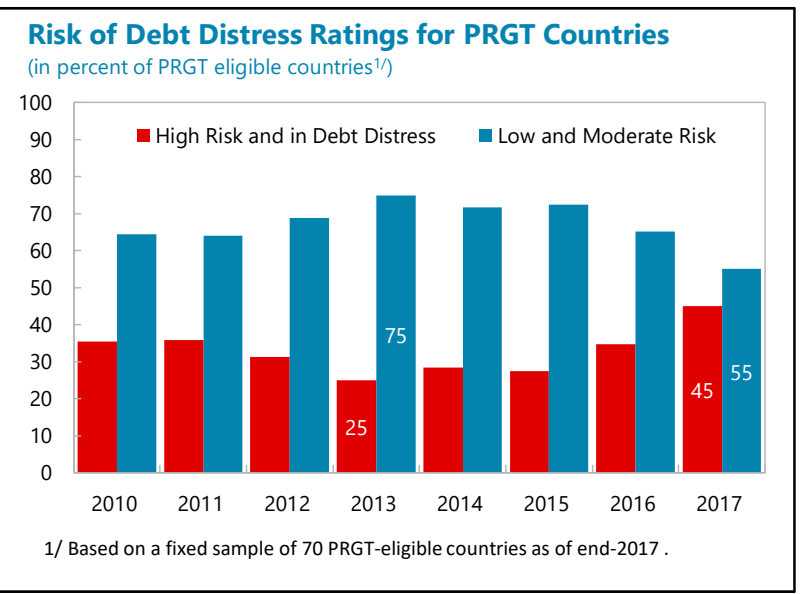
higher than the annual average before the global financial crisis.

Rising debt vulnerabilities and sustained high demand for concessional resources pose financial risks to the PRGT. The total share of PRGT credit outstanding to vulnerable PRGT countries (i.e., countries at high risk of debt distress or in debt distress) has nearly tripled since 2013 increasing to about 30 percent at end 2017 (SDR 1.9 billion). This exceeds the peak observed following the 2008 global financial crisis and amounts to roughly half the PRGT reserve account balance. Moreover, credit risks within the group of vulnerable PRGT countries are increasingly concentrated in a small number of relatively large borrowers. Financial risks to the PRGT may increase further with potentially large program requests in the pipeline and fewer PRGT-eligible members presumed to use blended PRGT/GRA financing due to heightened debt vulnerabilities.

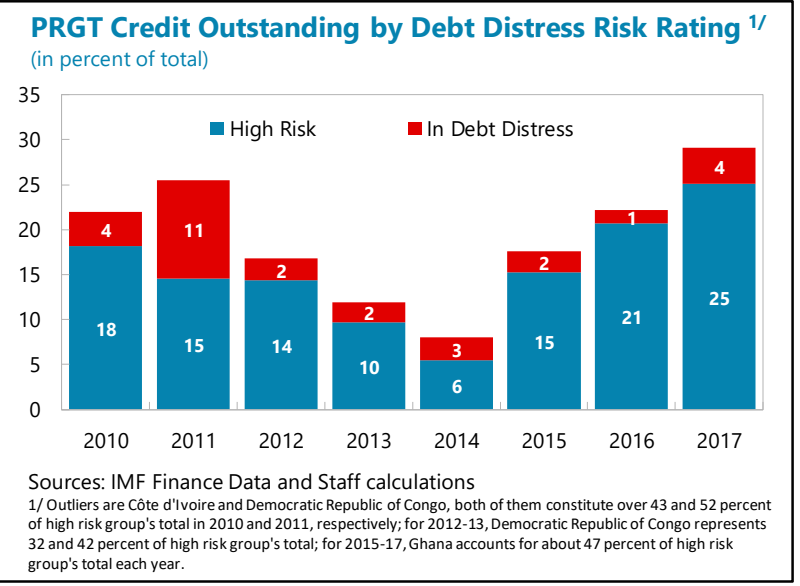

Against this backdrop, the Fund's multilayered risk management framework plays an important role in safeguarding scarce concessional resources while providing the needed support to member countries. While credit risk is inherent to IMF operations, a comprehensive set of measures exist to mitigate such risk and safeguard the Fund's limited concessional resources. In addition to the Fund's de facto preferred creditor status, the IMF's lending policies on access are central to minimizing risks to the PRGT's lending portfolio. Beyond access norms and limits, mitigation tools when new arrangements are considered include phasing, program design, conditionality, assessments of central bank safeguards, non-concessional borrowing limits, and policies on arrears resolution. Financing requests include assessments of members' capacity to implement adjustment policies and repay the Fund.

Note: Risks ratings are from the most recent Bank-Fund Debt Sustainability Analysis (DSA) for each PRGT-eligible country.

1/ See Macroeconomic Developments and Prospects in Low-Income Developing Countries. 


\section{DEMAND FOR PRGT CONCESSIONAL LENDING}

\section{Key messages:}

- Demand for PRGT resources remained elevated in 2017 , but may moderate somewhat in 2018.

- Updated longer-term demand estimates are broadly unchanged from last year, and remain generally consistent with resources under the self-sustaining PRGT financing framework adopted in 2012.

6. Demand for PRGT resources in $\mathbf{2 0 1 7}$ was elevated for the third year in a row (Table 1). While multi-year program commitments and observed annual disbursements are both measures of demand, Fund resources are managed on a commitment basis to ensure fulfillment of resource obligations. On either basis, the and 2). demand for concessional resources is historically very volatile and tends to move with economic cycles (Figures 1

- Total PRGT commitments in 2017 rose to SDR 1.7 billion, the highest amount since the global financial crisis in 2009. Eight new Extended Credit Facility (ECF) arrangements were concluded for a total of SDR 1.5 billion, five augmentations of access under PRGT arrangements were approved for SDR 223 million, and one RCF emergency loan of SDR 11.7 million was granted.

- Disbursements in 2017, under a total of 20 financing arrangements and RCFs, amounted to SDR 724 million, compared with SDR 677 million in 2016, and the

Table 1. New PRGT Commitments in 2017 (In millions of SDRs; as of end-December 2017)

\begin{tabular}{lrr} 
Country & Board Approval & Amount \\
\hline ECF Arrangements & & $\mathbf{1 , 4 9 1 . 8}$ \\
Benin & $04 / 07 / 2017$ & 111.4 \\
Cameroon & $06 / 26 / 2017$ & 483.0 \\
Chad & $06 / 30 / 2017$ & 224.3 \\
Guinea & $12 / 11 / 2017$ & 120.5 \\
Mauritania & $12 / 06 / 2017$ & 115.9 \\
Niger & $01 / 23 / 2017$ & 98.7 \\
Sierra Leone & $06 / 05 / 2017$ & 161.8 \\
Togo & $05 / 05 / 2017$ & 176.2 \\
ECF Augmentations & & $\mathbf{2 2 3 . 5}$ \\
Central African Republic & $12 / 15 / 2017$ & 39.0 \\
Central African Republic & $07 / 17 / 2017$ & 11.1 \\
Cote d'Ivoire 1/ & $06 / 19 / 2017$ & 54.2 \\
Madagascar & $06 / 28 / 2017$ & 30.6 \\
Mali & $07 / 07 / 2017$ & 88.6 \\
RCF Disbursements & & $\mathbf{1 1 . 7}$ \\
Gambia & & 11.7 \\
Total for 2017 & $06 / 26 / 2017$ & \\
\hline 1/ Blended GRA arrangement for an additional SDR 108 million. & \\
\hline
\end{tabular}
ten-year average of SDR 0.9 billion. ${ }^{9}$

\footnotetext{
${ }^{9}$ Disbursements are usually tranched over several years, implying less volatility from year to year. Moreover, to the extent that not all committed financing may be ultimately disbursed, for instance because of programs going off track, total disbursements can fall short of total commitments.
} 

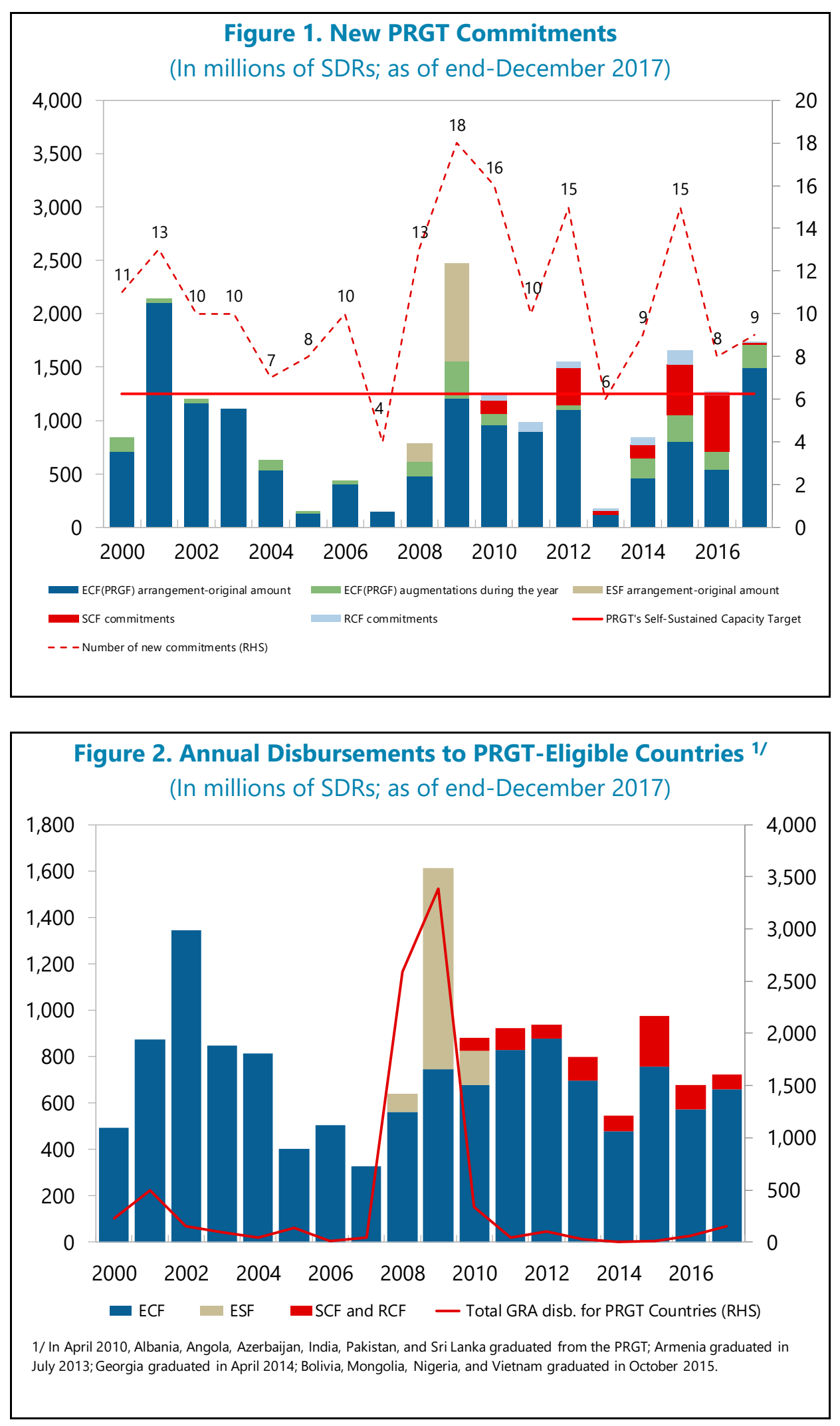
7. Demand in $\mathbf{2 0 1 8}$ is expected to moderate somewhat. New commitments are projected to reach about SDR 1.2 billion in 2018 based on a staff survey and actual commitments data through end-March 2018. This compares to average annual commitments of SDR 1.3 billion over the past ten years. Mainly as a result of strong demand in recent years, disbursements would continue rising and could reach SDR 1.3 billion in 2018. However, these near-term demand projections are subject to considerable uncertainties surrounding the program pipeline and possible requests for high access or augmentations of access in the event of shocks.

\section{Longer-term demand estimates are broadly unchanged from the previous update}

(Table 2). Given the considerable uncertainties around longer-term economic developments and use of PRGT resources, demand is projected using two benchmark scenarios (a low case and a high case). As in past years, the demand estimates reflect assumptions about countries' rising income levels that affect the use of blending and eventual graduations from PRGT eligibility. They also take into account current policies on access, the effect on future demand of the new large natural disaster window under the RCF, and factor in periodic general increases in access norms and limits across facilities in the long run that broadly match projected GDP developments and potential financing needs of PRGT-eligible countries. ${ }^{10}$ Based on this analysis, annual demand is projected to average between SDR 1.0 and 1.7 billion over the next ten years, broadly consistent with the self-sustaining PRGT financing framework, which targets a long-run annual lending capacity of about SDR 11/4 billion (see section on PRGT Capacity below). ${ }^{11}$ Looking over a twenty-year horizon, the range of demand estimates is somewhat higher, although subject to even greater uncertainty.

Table 2. Projected Demand for PRGT Resources Under Alternative Scenarios ${ }^{1 /}$ (In billions of SDRs)

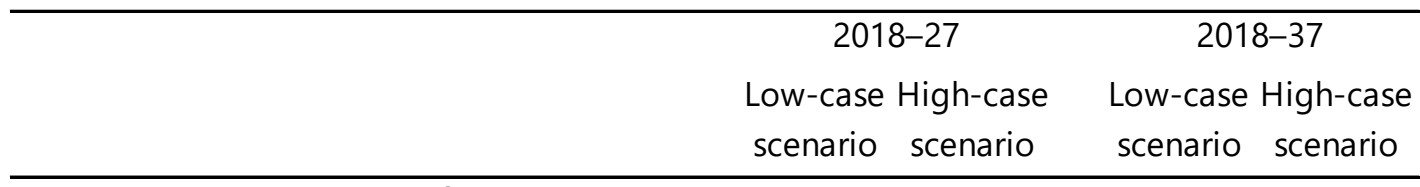

\section{Average annual demand ${ }^{2 /}$}

$\begin{array}{lllll}2017 \text { Update paper scenarios 3/ } & 0.88 & 1.60 & 1.17 & 2.11 \\ \text { Updated scenarios with RCF policy change 4/ } & 0.90 & 1.62 & 1.19 & 2.13 \\ \text { Current scenarios 4/ } & 1.00 & 1.68 & 1.18 & 2.07\end{array}$

1/ Based on historical data, the low-case scenario assumes that 30 percent of PRGT-eligible countries would resort to Fund financing, while the high-case scenario assumes 55 percent, in any given year.

2/ For outer years assumes access level increases in nominal SDR terms by 24.2 percent every three years, starting in 2020.

3/ Data from Update on the Financing of the Fund's Concessional Assistance and Debt Relief to Low-Income Countries, adjusted for the specified projection time ranges.

4/ Includes projected RCF demand for large natural disasters (see Large Natural Disasters-Enhancing the Financial Safety Net for Developing and Decision No. 16182-(17/35).

\footnotetext{
${ }^{10}$ Long-term forecasts of graduation from the PRGT are based on the per capita income criteria. Hence, demand could be lower than projected if PRGT-eligible countries acquired market access in the future, or higher when short-term vulnerabilities delay graduation from the PRGT.

${ }^{11}$ If the range of estimates were to fall clearly above (or below) the PRGT lending capacity, this would indicate that policies governing the PRGT (in particular eligibility, blending, access, and/or financing terms) are not sustainable over the longer-term (or overly restrictive) and changes would need to be considered, possibly together with other contingency measures under the three-pillar strategy (See Box 2).
} 


\section{SOURCES OF FINANCING FOR THE PRGT}

\section{Key messages:}

- The 2015 loan mobilization campaign has exceeded the target of SDR 11 billion, and the PRGT borrowing limit was increased accordingly.

- Progress has been limited on securing the remaining pledged subsidy contributions from past fund-raising rounds.

9. The operations of the PRGT are conducted through four Loan Accounts, four Subsidy Accounts, and the Reserve Account (Figure 3). Unlike lending under the General Resources Account (GRA), the PRGT operations are financed using an endowment model based on loan and subsidy resources. The balances accumulated in these accounts ensure the PRGT's ability to provide concessional assistance on a self-sustained basis, its lending capacity, and financial strength.

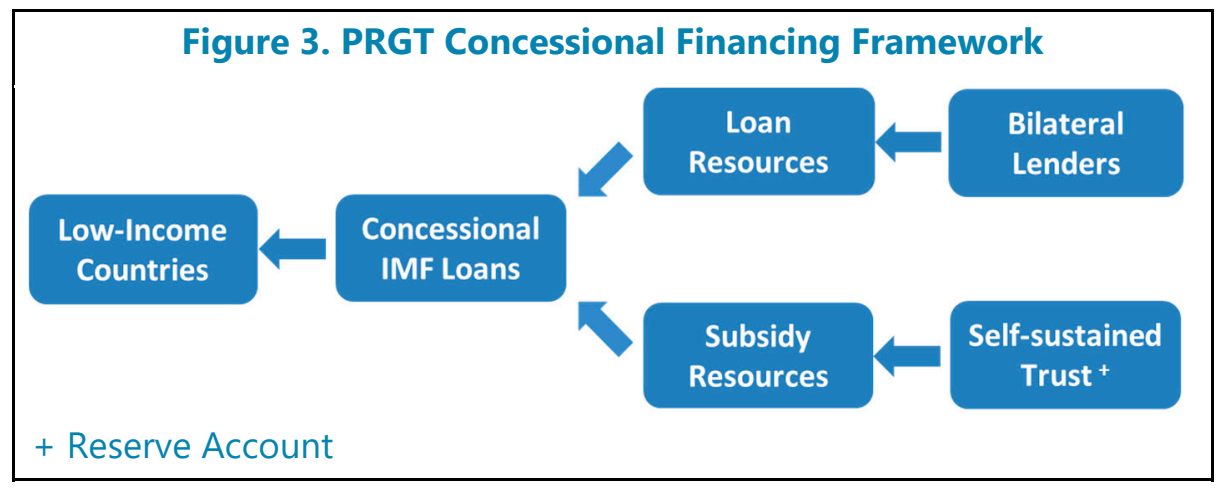

- Bilateral lenders provide loan resources. Loan accounts contain resources borrowed at three-month SDR interest rates or the six-month derived SDR interest rates from official creditors that are on-lent on a pass-through basis to PRGT-eligible countries. There are loan accounts dedicated to finance each PRGT facility (RCF, Standby Credit Facility (SCF), and ECF loan accounts), and a General Loan Account (GLA), which can finance any of the facilities.

- $\quad$ The self-sustained trust provides subsidy resources. Subsidy accounts contain bilateral contributions from members, from the Fund's own resources, and returns from the investment of their balances. The accounts provide the resources that enable the PRGT to extend loans to eligible members at below market interest rates although it acquires its loan resources at market interest rates. There are subsidy accounts dedicated to subsidizing interest payments for each PRGT facility (RCF, SCF, and ECF subsidy accounts), in addition to the General Subsidy Account (GSA), which may subsidize any of the facilities. The interest rate paid by member countries borrowing from the PRGT is subject to a mechanism that currently provides for zero interest on all PRGT credit. 
- $\quad$ The Reserve Account (RA) provides security to lenders. The RA was originally financed by the profits of gold sales in the late 1970s, reflows of the Trust Fund and Structural Adjustment Facility (SAF) repayments, as well as investment returns on balances held in it. The RA provides security to lenders to the PRGT and can meet obligations in the event of delayed payments by PRGT borrowers. It is also used to meet the Fund's cost of administering PRGT operations. Under the self-sustained PRGT framework, once subsidy accounts are fully drawn (which is expected to take about two decades), the balance in the RA, including investment income, will be used to subsidize concessional lending.

\section{A. Loan Accounts}

\section{Against a target of SDR 11 billion, the 2015 fund-raising round so far mobilized SDR 11.4 billion in new loan resources from 15 PRGT lenders, including two new lenders} (Brazil and Sweden). ${ }^{12}$ Loan providers have committed these new resources through traditional loan agreements, Note Purchase Agreements (NPAs) and augmentations of existing agreements (Table 3). Nine lenders participate in the encashment regime of the PRGT. ${ }^{13}$ Five loan agreements are denominated in SDRs, five in euros, four in U.S. dollars, and one in renminbi. In January 2018, the cumulative borrowing limit under the PRGT was raised by SDR 1 billion to SDR 38.5 billion to accommodate the above-target level of new loan resources mobilized. ${ }^{14}$

\section{Uncommitted PRGT loan resources, from both existing and new loan agreements,} totaled SDR 13.9 billion at end-February 2018. While the bulk of loan resources (SDR 8.8 billion) are in the GLA, the rest is allocated among facility-specific accounts: ECF loan account (SDR 4.8 billion), the SCF loan account (SDR 150 million), and the RCF loan account (SDR 150 million). Uncommitted PRGT loan resources, net of a liquidity buffer of SDR 3.3 billion for possible encashment calls, are deemed sufficient to meet expected demand well into the next decade. Based on the amended PRGT Instrument, loan resources from previous mobilization rounds will be drawn before new resources are activated. ${ }^{15}$

\footnotetext{
12 The current PRGT loan mobilization round was endorsed by the Executive Board in 2014 with the objective to raise additional borrowing capacity for the PRGT of up to SDR 11 billion, which would be adequate to meet demand for loan resources over the medium term (Update on the Financing of the Fund's Concessional Assistance and Proposed Amendments to the PRGT Instrument).

13 Under the encashment regime, the PRGT provides participating lenders with the right to request early repayment of outstanding claims in case of balance of payments need. The Fund repays the requesting lender by drawing down resources committed to the PRGT by other participating lenders, by means of a liquidity buffer of 20 percent of the loan amounts committed by lenders in the encashment regime.

${ }^{14}$ Borrowing limits have been in place for the PRGT since 1989 to ensure that new PRGT borrowing would not take place without prior consultation with loan account creditors regarding the justification for such borrowing and the adequacy of the Reserve Account. See Modifying the Poverty Reduction Growth Trust (PRGT) Cumulative Borrowing Limit and Decision No. 16323-(18/1).

15 Decision No. 16051-(16/86), adopted September 20, 2016, amended the drawing mechanism under the PRGT Instrument to prioritize the use of resources from agreements effective earlier than May 31, 2014, before drawing on new resources. This amendment took effect on December 20, 2016, following consents from all affected PRGT lenders with undrawn loan balances.
} 


\begin{tabular}{lrccccc|}
\multicolumn{5}{c}{} & \multicolumn{2}{c}{ Table 3. New PRGT Loan Agreements } \\
& (In millions of SDRS; as of end-February 2018) & \\
\hline Country & Amount & $\begin{array}{c}\text { Effective } \\
\text { Date }\end{array}$ & Media & Type & Account & Encashment \\
\hline Belgium & 350 & $8 / 30 / 2017$ & EUR & Loan & ECF & No \\
Brazil & 500 & $6 / 1 / 2017$ & USD & NPA & GLA & Yes \\
Canada & 500 & $1 / 10 / 2017$ & USD & Loan & GLA & No \\
China & 800 & $4 / 21 / 2017$ & RMB & NPA & GLA & Yes \\
Denmark & 300 & $11 / 17 / 2016$ & EUR & Loan & GLA & No \\
France & 2,000 & $2 / 1 / 2018$ & SDR & Loan & ECF & Yes \\
Italy & 400 & $7 / 17 / 2017$ & SDR & Loan & ECF & Yes \\
Japan & 1,800 & $4 / 20 / 2017$ & SDR & NPA & GLA & Yes \\
Korea & 500 & $12 / 20 / 2016$ & SDR & Loan & GLA & Yes \\
Netherlands & 500 & $12 / 20 / 2016$ & EUR & Loan & GLA & No \\
Norway & 300 & $11 / 17 / 2016$ & USD & Loan & RCF/SCF & No \\
Spain & 450 & $2 / 22 / 2017$ & EUR & Loan & GLA & Yes \\
Sweden & 500 & $11 / 17 / 2016$ & USD & Loan & GLA & Yes \\
Switzerland & 500 & $8 / 30 / 2017$ & EUR & Loan & GLA & No \\
United Kingdom & 2,000 & $1 / 23 / 2017$ & SDR & NPA & ECF & Yes \\
Total & $\mathbf{1 1 , 4 0 0}$ & & & & & \\
& & & & & & \\
& & & & & & \\
\hline
\end{tabular}

\section{B. Subsidy Accounts}

\section{At end-December 2017, total balances in the PRGT Subsidy Accounts amounted to} SDR 3.6 billion (Table 4). In addition, SDR 239 million is presumed to be available from the PRG-HIPC Trust (see below). ${ }^{16}$ The Subsidy Accounts are financed through IMF and bilateral contributions from members, the latter being in the form of distributions of the windfall gold sale profits, grants or income on investments (Appendix Tables 6-7). PRGT Subsidy Account balances do not include amounts pledged but not yet received under various fund-raising rounds (Appendix Tables 2-5).

\section{At end-February 2018, total pending} subsidy contributions amounted to about

Table 4. Balances of PRGT Accounts (In billions of SDRs; as of end-December 2017)

\begin{tabular}{|lc|}
\hline Account & Amount \\
\hline Subsidy Accounts & $\mathbf{3 . 5 8}$ \\
General Subsidy Account & 2.50 \\
ECF Subsidy Account & 1.03 \\
RCF Subsidy Account & 0.02 \\
SCF Subsidy Account & 0.03 \\
Reserve Account & $\mathbf{3 . 8 2}$ \\
\hline Memorandum item: & \\
PRG-HIPC Trust & 0.24 \\
\hline
\end{tabular}

SDR 178 million from 27 countries (Figure 4 and Appendix Table 8). Since the April 2017 Update paper, the Netherlands disbursed the last installment of SDR 1.4 million to complete its pledge

\footnotetext{
${ }^{16}$ The PRG-HIPC Trust was established in 1997 to provide assistance to LICs by making grants and/or loans to reduce external debt burden to sustainable levels and to subsidize the interest payments. Upon liquidation, surplus funds shall be made available for self-sustained PRGT operations unless contributors request otherwise. See Section III bis and Section V, paragraph 2 of the PRG-HIPC Trust Instrument, as annexed to Decision No. 11436-97/10 and as amended.
} 
under the 2009 fundraising round and SDR 39.6 million were received from Ireland, South Africa and Switzerland to meet pledges of subsidy contributions related to the distributions of the remaining reserves attributable to the windfall gold sale profits (Appendix Table 5). As of end-February 2018, about 89 percent of the total distributions of the general reserve attributable to windfall profits of the gold sales has been received, compared with the 95 percent pledged by 165 countries.

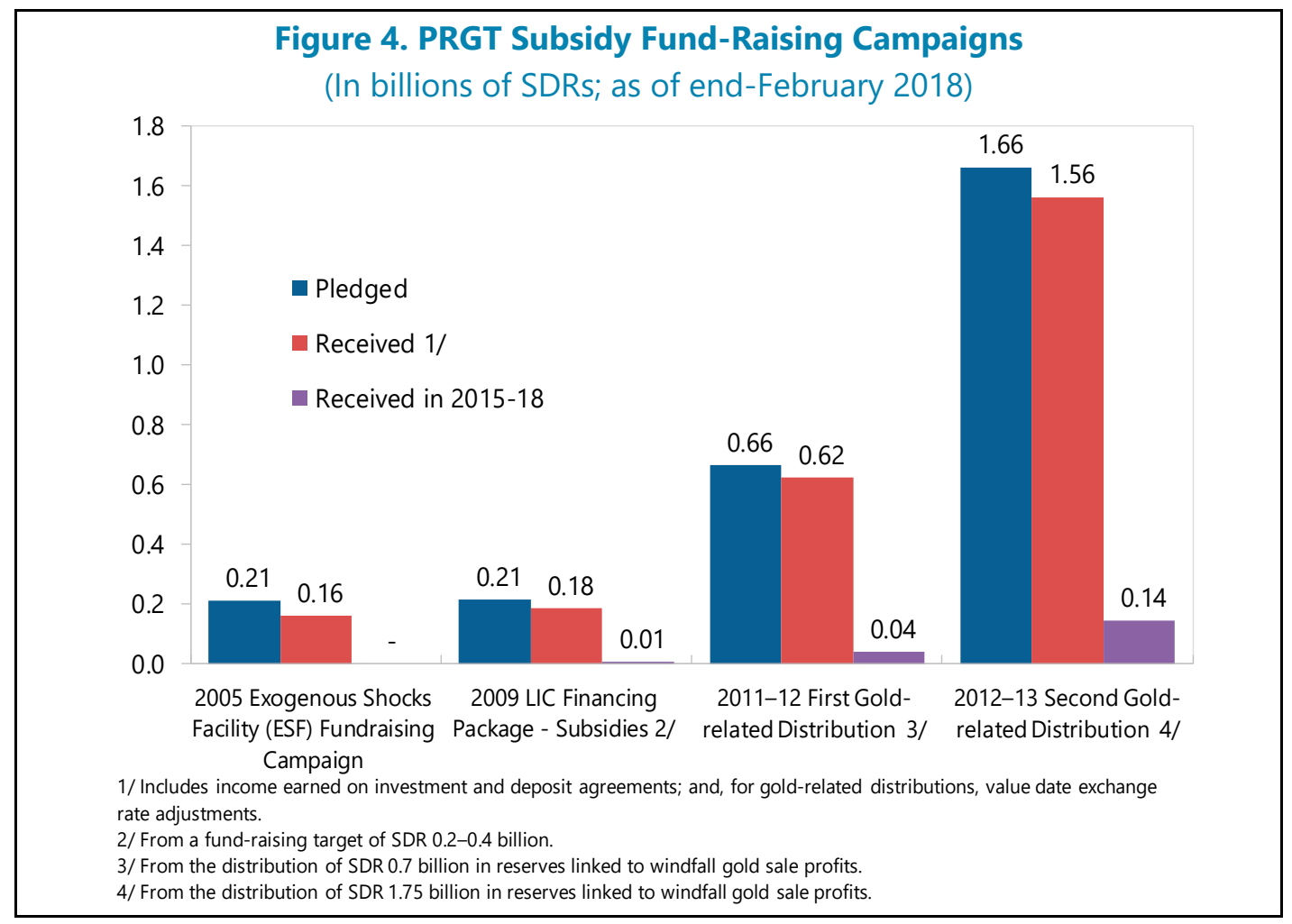

14. Income from bilateral deposit and investment agreements is still falling well short of pledged amounts. Seven member countries have pledged contributions to the PRGT to be fulfilled from investment returns on bilateral deposit and investment agreements. At end-2017, contributions generated from investment agreements reached only SDR 10.4 million in NPV terms compared with total pledges to the PRGT of SDR 61.4 million in NPV terms. ${ }^{17}$ In the context of the implementation of the new investment strategy for PRGT assets, ${ }^{18}$ investment agreements with Botswana, China, Morocco and Peru have been extended to allow for generating earlier pledged amounts that have not materialized due to the low return environment (Appendix Table 4). There are also twenty bilateral deposit agreements for the benefit of the PRG-HIPC trust that will expire in December 2018 (Appendix Table 7). Staff will contact the respective authorities in due course to discuss options for extension or repurposing of these agreements in order to generate additional subsidy contributions. ${ }^{19}$

\footnotetext{
17 The investment provided by Trinidad and Tobago has been repaid at maturity before generating the pledged amount of contribution.

18 See Decision No. 16253-(17/70), adopted July 28, 2017.

${ }^{19}$ One of these twenty (with Saudi Arabia) has been already repurposed for the benefit of the PRGT.
} 


\section{Reserve Account}

\section{The PRGT Reserve Account continues to provide adequate security to PRGT loan}

providers. As of end-December 2017, the Reserve Account balance stood at SDR 3.8 billion, about SDR 64 million lower than at end-2016 as administrative fees reimbursed to the GRA exceeded net investment returns. The Reserve Account balance covers about 59 percent of total PRGT obligations and remains substantially higher than total PRGT repayments falling due in 2018 (Figure 5 and Appendix Table 9). The reserve ratio remains well above the 40 percent historical average prior to the delivery of debt relief through the HIPC and Multilateral Debt Relief Initiative (MDRI), and, absent large shocks to PRGT demand or credit portfolio (see below), is expected to gradually increase over the medium to long term. ${ }^{21}$

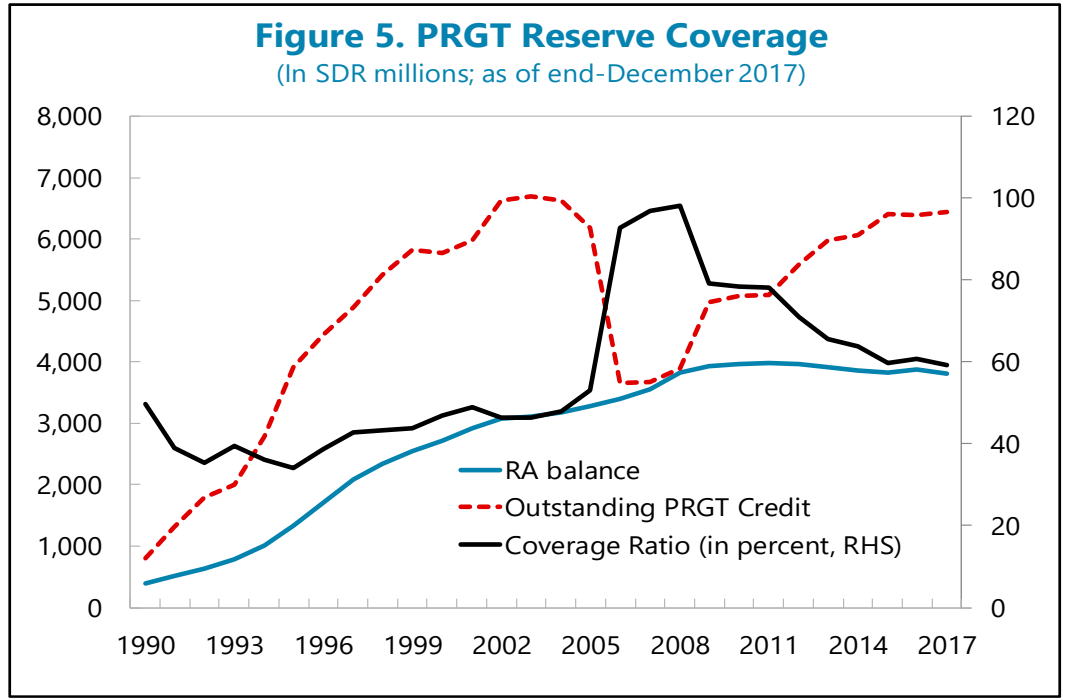

\section{PRGT CAPACITY: ASSESSING ADEQUACY AND SELF-SUSTAINABILITY}

Key messages:

- The PRGT self-sustained capacity remains intact, at an estimated SDR 1.31 billion in annual lending capacity.

- The PRGT's lending capacity is generally robust to short-term demand shocks, but can be more sensitive to factors affecting the PRGT endowment, which requires regular monitoring.

\footnotetext{
${ }^{21}$ As noted above, income from investments will allow the RA balance to increase until subsidy account resources are fully drawn.
} 


\section{In 2012, the Executive Board adopted a three-pillar strategy to make the PRGT's} concessional lending self-sustaining (Box 2). The strategy enables the IMF to provide assistance to LICs on a concessional basis without the need for regular grant fundraising rounds from its members. The resources to subsidize the interest on PRGT credit are derived from the balances and investment income in the Subsidy and Reserve Accounts as discussed above. The self-sustained PRGT framework requires regular monitoring of capacity and demand, and a set of policies—including on access, financing terms, blending, and PRGT eligibility—that are consistent with the principle of self-sustainability.

\section{The PRGT's self-sustained capacity is intact, with an estimated annual lending capacity} of SDR 1.31 billion. This is broadly in line with the April 2017 Update. The self-sustained capacity is estimated based on a range of factors that impact both subsidy needs and available resources over the long-run. These include near-term PRGT demand and the level of credit outstanding, the balances of the PRGT Subsidy and Reserve Accounts, the investment returns ${ }^{22}$ on those balances, the subsidy element of PRGT loans, ${ }^{23}$ and the reimbursement to the GRA for administrative expenses.

\section{The self-sustained lending capacity remains robust under different near-term demand}

shock scenarios. Demand for concessional resources is historically very volatile, especially on a commitment basis, ${ }^{24}$ which during 2000-17 ranged from SDR 65 million (2007) to a peak of SDR 2.5 billion (2009). In the event that annual PRGT demand were to remain at elevated levels in 2019-20, one-standard deviation over historical averages, the estimated self-sustained lending capacity would still remain above targeted capacity (Figure 6). However, under exceptionally high demand at two-standard deviations over the historical averages, capacity would fall to SDR 1.24 billion. Moreover, elevated demand would boost credit outstanding and reduce the reserve coverage ratio temporarily, although it would remain above 40 percent under most scenarios. In these circumstances, the Board could consider contingent measures under the three-pillar strategy, as demand would have exceeded the self-sustained capacity target by a large margin for six years running. Contingent measures may also be appropriate if longer-term demand estimates were to increase relative to the current ten-year range of SDR 1.0-1.7 billion (See section on Demand for PRGT Concessional Lending above and Box 2).

\footnotetext{
${ }^{22}$ For projection purposes, the medium to long-run investment returns are assumed as the 6-month SDR rate plus a 90 basis point fixed margin as targeted under the new investment strategy for PRGT assets approved in March 2017.

23 The subsidy element of PRGT loans is determined by the spread between interest rates charged by PRGT loan providers and the concessional rates set for loans under PRGT facilities. Assumptions concerning concessional interest rates applied to loans under the PRGT's concessional facilities are aligned with the Executive Board's decisions on the interest rate mechanism. On that basis, interest rates on all PRGT loans are set to zero until end-2018 and automatically adjusted based on SDR rates assumed for the preceding period.

${ }^{24}$ As noted above, Fund resources are managed on a commitments basis as a safeguard to the membership that ensures that the IMF's resource obligations can be fulfilled. If disbursements fall short of commitments, associated savings in subsidy needs would, all else being equal, bolster the PRGT and its lending capacity going forward.
} 
Figure 6. Self-Sustained Capacity and Reserve Account Coverage Under Peak Demand
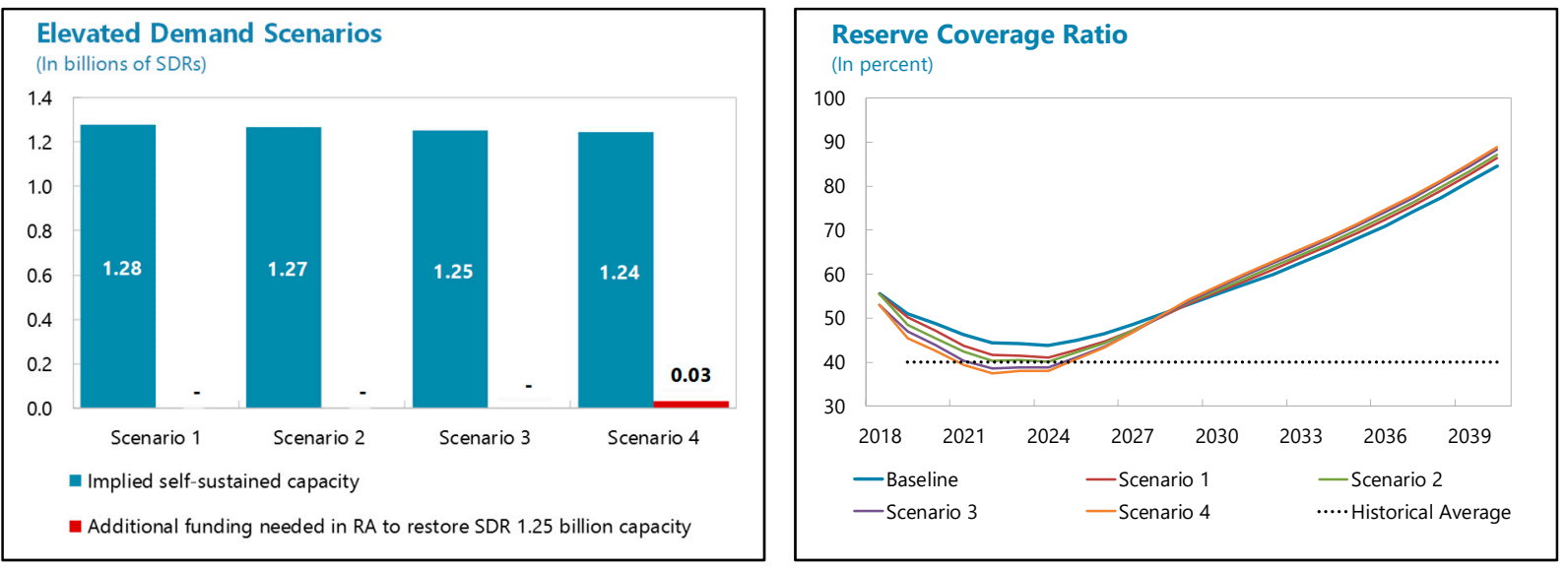

Memorandum Items:

Scenario 1 : Baseline demand in demand of 2003-17 in 2019-20 plus one standard deviation (SDR 1.7 billion).

Scenario 2 : Demand in 2018 is the average of 2003-17 plus two standard deviations (SDR 2.3 billion).

Scenario 3 : Demand in 2018 is SDR 2 billion; 2019-20 is the average of 2003-17 plus one standard deviation.

Scenario 4 : Demand in 2018 is SDR 2 billion; 2019 is the average 2003-17 plus two standard deviations.

\section{Box 2. Three-Pillar Strategy of the Self-Sustaining PRGT Financing Framework}

A three-pillar strategy to ensure that the PRGT has sufficient resources to meet projected demand for IMF concessional lending over the long-term was set out in the paper Proposal to Distribute Remaining Windfall Gold Sales Profits and Strategy to Make the Poverty Reduction and Growth Trust Sustainable. It consists of:

- $\quad$ A base envelope of about SDR 11/4 billion in annual average lending capacity, which is expected to cover concessional lending needs over normal periods. While financing commitments can vary substantially from year to year, the self-sustaining PRGT can build up capacity in years with low levels of new lending commitments and draw down capacity in years when demand is high. This implies that the base envelope could cover periods where demand in individual years could be much higher, as long as fluctuations average out over a number of years.

- $\quad$ Contingent measures that can be put in place when average financing needs exceed the base envelope by a substantial margin for an extended period. If the Executive Board considers that the self-sustaining capacity will decline substantially below SDR $1 \frac{11 / 4}{4}$ billion, it could decide to activate a range of contingent measures, including: (i) reaching additional understanding on bilateral fund-raising efforts among a broad range of the membership; (ii) the suspension for a limited period of the reimbursement of the GRA for PRGT administrative expenses; and (iii) modifications of access, blending, interest rate, and eligibility policies to reduce the need for subsidy resources.

- A principle of self-sustainability under which future modifications for low-income countries would be expected to ensure that the demand for IMF concessional lending can reasonably be met with the resources available under the first and second pillars under a plausible range of scenarios."

1/ Specifically, any modifications to access, financing terms, blending, eligibility and other relevant policies would be expected to be designed in a way that average demand in normal periods could be covered through the resources available under the first pillar, and that periods of high financing needs (e.g., as a result of significant shocks, could be covered through the contingent mechanisms). 
19. The viability of the self-sustaining PRGT requires regular monitoring of factors that directly impact the PRGT's endowment.

These include in particular investment returns of PRGT assets, payment of pledged contributions, the Reserve Account level (Table 5), the level of global interest rates and associated subsidization needs, and reimbursement to the GRA of the PRGT's administrative expenses.

- Consistent with the new investment strategy for PRGT assets approved by the Executive Board in 2017, staff estimates assume an average investment premium (excess return) over time of 90 basis points above the six-month derived SDR interest rates. If the long-run premium were to fall short by 40 basis points, it would reduce self-sustained capacity by

Table 5. Sensitivity of Self-Sustained Capacity

\begin{tabular}{|c|c|c|}
\hline \multirow[b]{2}{*}{ Deviations from Baseline } & \multicolumn{2}{|c|}{ Change in Capacity } \\
\hline & $\begin{array}{l}\text { in SDR } \\
\text { millions }\end{array}$ & $\begin{array}{l}\text { in \% of } \\
\text { target }\end{array}$ \\
\hline Investment premium & & \\
\hline Decrease $40 \mathrm{bp}$ & -108.9 & -8.7 \\
\hline SDR rate & & \\
\hline Decrease 100 bp & 18.9 & 1.5 \\
\hline $\begin{array}{l}\text { GRA Reimbursement } \\
\text { Increase SDR } 15 \mathrm{mn}\end{array}$ & -72.0 & -5.8 \\
\hline Pledged Contributions & & \\
\hline Decrease SDR $300 \mathrm{mn}$ & -67.5 & -5.4 \\
\hline PRGT Credit event & & \\
\hline Medium borrower & -15.0 & -1.2 \\
\hline Large borrower & -67.7 & -5.4 \\
\hline
\end{tabular}
about SDR 109 million, or nearly 9 percent of the lending capacity target.

- By contrast, the impact of interest rate differences from the assumed profile for the SDR rate is relatively muted, as earnings on PRGT assets and net lending costs (interest paid to loan providers minus interest charged to borrowers under the PRGT interest rate framework) both adjust with interest rates and thus act to hedge the self-sustained capacity. When estimating the impact from a scenario that compares two long-run equilibrium interest rates (450 versus 350 basis points covering a range of historical averages before the global financial crisis), the capacity difference is only about SDR 19 million.

- Baseline lending capacity estimates assume that all pledges will be fulfilled. Failure by Fund-members to fulfill some or all of their pledged subsidy contributions under previous fundraisings discussed above would entail a reduction in the PRGT's self-sustained lending capacity of up to SDR 67.5 million. Conversely, to the extent that loan resources are remunerated at below market interest rates, such as the United Kingdom's NPA, implicit subsidy contributions arise that can bolster lending capacity. ${ }^{25}$

- An increase in administrative expenses relative to baseline assumptions, by SDR 10 million (relative to the assumed SDR 65 million) annually would entail a reduction in the PRGT's self-sustained lending capacity of SDR 72 million.

- Under the self-sustained PRGT framework, the investment income from the Reserve Account will eventually be used to subsidize concessional financing. However, a potential new case of

\footnotetext{
25 The 2015 and 2017 NPAs with the United Kingdom include an interest rate capped at 0.05 percent, largely below the SDR rate, thus generating potentially large implicit subsidy to the PRGT.
} 
protracted arrears would reduce the Reserve Account balance available for investment purposes. For illustration purposes, if only one medium or large PRGT borrower currently at high risk of debt distress were to completely default on its repayments the PRGT long-run lending capacity would drop between an estimated SDR 15 million to SDR 68 million, annually. ${ }^{26}$

\section{FINANCING DEBT RELIEF}

\section{Key messages:}

- The Catastrophe Containment and Relief Trust remains underfunded, both with respect to the original target and when considering the doubling of countries' quotas under the $14^{\text {th }}$ General Review of Quotas.

- Disbursements of pledged contributions and commitments to provide necessary additional resources to finance debt relief are still pending from several members.

\section{A. Catastrophe Containment and Relief Trust}

20. The CCR Trust remains underfunded. Created in February 2015, the CCR Trust is designed to provide grants for debt relief to eligible countries ${ }^{27}$ under two windows: (i) the first dedicated to interventions after catastrophic natural disasters; and (ii) the second to be activated in case of major public health disasters with the potential to spill over across international borders. Operations were initially funded by repurposing the resources from its predecessor, the Post-Catastrophe Debt Relief (PCDR) Trust, together with residual MDRI-I funds, and transfers from members' balances in the MDRI-II Trust (see Appendix 10). ${ }^{28}$ These initial funds were sufficient to grant support at the time of its establishment; however, additional resources are needed to enable the CCR Trust to meet funding needs for future qualifying catastrophe relief. ${ }^{29}$ Thus, at the time of its creation, a mobilization campaign called on 58 advanced and emerging market members to raise US\$150 million (equivalent to SDR 106 million) in bilateral contributions. However, to date, only 6 members pledged to contribute a total amount of US\$93.3 million (equivalent to SDR 59 million), of which US\$82.3 million has been received, which is US\$67.7 million short of the fundraising target.

\footnotetext{
26 This range assumes total loss of projected repayments from a borrower either (i) of median size (in terms of outstanding PRGT credit) or (ii) above the $75^{\text {th }}$ percentile of all current PRGT borrowers.

${ }^{27}$ Only a subgroup of PRGT countries are eligible for assistance under the CCRT. Requirements include: (i) a per capita income below the International Development Association's (IDA) operational cutoff (currently US\$1,165) or (ii) limited to Small States (i.e. a population below 1.5 million): a per capita income below twice the IDA cutoff. Moreover, to qualify under the CCRT's catastrophic disaster window, the shock must have (i) directly affected at least one third of the population; and (ii) destroyed more than a quarter of the country's productive capacity or caused damage deemed to exceed 100 percent of GDP. The second window is used to provide relief when an eligible member suffers a qualifying public health disaster.

28 The CCR Trust has extended debt relief to three countries severely hit by the Ebola crisis: Guinea (SDR 21.4 million), Liberia (SDR 25.8 million), and Sierra Leone (SDR 20.7 million). In 2010, Haiti had received SDR 178 million in debt stock relief under the former PCDR Trust.
}

${ }^{29}$ See Proposal to Enhance Fund Support for Low-Income Countries Hit by Public Health Disasters. 
As of end 2017, the total CCR Trust contributions amount to SDR 97.8 million, for a total balance of the Trust of SDR 144 million.

\section{New contributions are essential to strengthen the Fund's emergency support to} countries hit by catastrophic disasters. As about half of the responses from solicited members are still pending, it is critical that outstanding formal responses be translated into actual pledges and contributions to enhance the Fund's emergency assistance. Moreover, it should be noted that the original fundraising target was based on the $13^{\text {th }}$ General Review of Quotas. With CCR Trust debt relief in public health disasters generally capped at 20 percent of quota, the quota increases under the $14^{\text {th }}$ General Review of Quotas are estimated to have increased the initial resource shortfall noted above by another SDR 100 million. Options for further enhancing CCR assistance under the forthcoming LICs Facilities Review will need to be considered alongside with proposals to address funding shortfalls and put the CCR Trust on a more sustainable footing.

\section{B. Highly Indebted Poor Countries Initiative}

\section{The HIPC Initiative is nearly complete, having alleviated debt burdens in $\mathbf{3 6}$ out of} 39 eligible countries. Debt relief delivered by the IMF under the HIPC Initiative has been financed from gold sales and bilateral contributions for a total amount of SDR 2.6 billion (Appendix Table 11). Three pre-decision point countries (Eritrea, Somalia, and Sudan) have yet to start the process of qualifying for debt relief under the Initiative. While Eritrea has no outstanding obligations to the Fund, Sudan and Somalia have protracted arrears (see section C below).

\section{Outstanding pledges from eight countries, once disbursed, will replenish the}

PRG-HIPC Trust. The IMF and the World Bank jointly committed to provide HIPC and "beyond-HIPC" debt relief to Liberia in 2008. While a large share of the membership underwrote contributions to Liberia's financing package for debt relief, pending contributions totaling SDR 17.7 million (March 2008 NPV terms) are yet to be received from eight countries (Table 6). While these countries had pledged to contribute to Liberia's debt Table 6. Pending Disbursements to Finance Debt Relief to Liberia (In millions of SDRs; in March 14, 2018 NPV terms) relief in 2008, the Trust provided for the shortfall in the interim.

\section{Protracted Arrears Cases}

24. At end-February 2018, overdue financial obligations to the Fund from two protracted arrears cases totaled SDR 1.2 billion. Sudan and Somalia have been in arrears to the Fund since 1984 and 1987, respectively. Sudan accounts for the largest share of the total amount of the arrears (about 80 percent). Under a Staff-Monitored Program since 2016, Somalia is pursuing reforms to 
establish a track record of sound policy performance towards normalization of relationship with the international community and eventual debt relief. However, arrears clearance has been complicated by domestic conflict, international sanctions and the need for additional financial resources.

\section{Providing debt relief for Sudan and Somalia would require additional financing, hence} fundraising. The original cost estimates for the HIPC initiative did not account for debt relief for Somalia and Sudan. Thus, new resources would need to be raised once these countries are ready to clear their arrears and undertake the HIPC initiative and potentially "beyond-HIPC" debt relief. ${ }^{32,33}$ When the time is appropriate, the approach developed for Liberia's debt relief, including the financing modalities, could provide a useful framework for these two cases.

\footnotetext{
32 In the context of the MDRI in 2005, the G-8 committed that donors would provide the extra resources necessary for full debt relief at completion point for the remaining protracted arrears cases. See G-8 Financing Ministers' Conclusion on Development (2005).

33 Sudan and South Sudan reached the so-called "zero option" agreement in September 2012, whereby Sudan would retain all external liabilities after the secession of South Sudan, provided that the international community gave firm commitments to the delivery of debt relief within two years. Absent such a commitment, Sudan's external debt would be apportioned with South Sudan based on a formula to be determined. The two parties have agreed to extend this agreement on several occasions, most recently in October 2016 by another two years.
} 


\begin{tabular}{|c|c|c|c|c|c|c|c|}
\hline \multicolumn{8}{|c|}{$\begin{array}{l}\text { Appendix Table 1. PRGT_Borrowing Agreements } \\
\text { (In millions of SDRs; as of end-February 2018) }\end{array}$} \\
\hline & \multirow[b]{2}{*}{$\begin{array}{c}\text { Effective date of } \\
\text { agreement }\end{array}$} & \multirow[b]{2}{*}{$\begin{array}{l}\text { Expiration date } \\
\text { for drawings }\end{array}$} & \multirow[b]{2}{*}{$\begin{array}{c}\text { Loan } \\
\text { commitments }\end{array}$} & \multicolumn{2}{|c|}{ Amount Disbursed } & \multirow{2}{*}{$\begin{array}{l}\text { Early repayment } \\
\text { related to the } \\
\text { MDRI }\end{array}$} & \multirow[b]{2}{*}{$\begin{array}{c}\text { Amount } \\
\text { outstanding }\end{array}$} \\
\hline & & & & Amount & $\begin{array}{l}\text { In percent of } \\
\text { commitment }\end{array}$ & & \\
\hline \multicolumn{8}{|l|}{ Belgium } \\
\hline National Bank of Belgium 1/ & 02-Jul-1999 & 31-Dec-2014 & 350.0 & 350.0 & 100.0 & 163.0 & 24.1 \\
\hline National Bank of Belgium 3/ & 12-Nov-2012 & 31-Dec-2024 & 350.0 & 350.0 & 100.0 & - & 350.0 \\
\hline National Bank of Belgium 3/ & 30-Aug-2017 & 31-Dec-2024 & 350.0 & - & - & - & - \\
\hline \multicolumn{8}{|l|}{ Brazil } \\
\hline Banco Central do Brazil 2/ & 01-Jun-2017 & 31-Dec-2024 & 500.0 & - & - & - & - \\
\hline \multicolumn{8}{|l|}{ Canada } \\
\hline Government of Canada & 22-Feb-1989 & 31-Dec-1997 & 300.0 & 300.0 & 100.0 & 16.1 & - \\
\hline Government of Canada & 09-May-1995 & 31-Dec-2005 & 400.0 & 400.0 & 100.0 & 143.3 & - \\
\hline Government of Canada 2/ & 05-Mar-2010 & 31-Dec-2024 & 500.0 & 151.5 & 30.3 & - & 137.3 \\
\hline Government of Canada 2/ & 10-Jan-2017 & 31-Dec-2024 & 500.0 & - & - & - & - \\
\hline \multicolumn{8}{|l|}{ China } \\
\hline Government of China 1/ & 05-Jul-1994 & 31-Dec-2014 & 200.0 & 200.0 & 100.0 & 71.3 & 2.2 \\
\hline People's Bank of China 3/ & 03-Sep-2010 & 31-Dec-2024 & 800.0 & 793.6 & 99.2 & - & 747.3 \\
\hline People's Bank of China 2/ & 21-Apr-2017 & 31-Dec-2024 & 800.0 & - & - & - & - \\
\hline \multicolumn{8}{|l|}{ Denmark } \\
\hline National Bank of Denmark & 03-May-2000 & 31-Dec-2003 & 100.0 & 100.0 & 100.0 & 100.0 & - \\
\hline National Bank of Denmark 2/ & 28-Jan-2010 & 31-Dec-2024 & 200.0 & 39.5 & 19.7 & - & 36.7 \\
\hline National Bank of Denmark 2/ 4/ & 17-Nov-2016 & 31-Dec-2024 & 300.0 & - & - & - & - \\
\hline \multicolumn{8}{|l|}{ Egypt } \\
\hline Central Bank of Egypt 1/ & 13-Jun-1994 & 31-Dec-2014 & 155.6 & 155.6 & 100.0 & 21.9 & 15.3 \\
\hline \multicolumn{8}{|l|}{ France } \\
\hline Agence Française de Développement 5/ & 05-Apr-1988 & 31-Dec-1997 & 800.0 & 800.0 & 100.0 & - & - \\
\hline Agence Française de Développement 5/ & 03-Jan-1995 & 31-Dec-2005 & 750.0 & 750.0 & 100.0 & - & - \\
\hline Agence Française de Développement 1/ 5/ & 17-Dec-1999 & 31-Dec-2014 & $1,350.0$ & $1,350.0$ & 100.0 & 485.2 & 226.8 \\
\hline Agence Française de Développement 5/ 6/ & 20-Aug-2009 & 31-Dec-2014 & 670.0 & 670.0 & 100.0 & - & 468.0 \\
\hline Bank of France 3/ & 03-Sep-2010 & 31-Dec-2018 & $1,328.0$ & $1,284.6$ & 96.7 & - & $1,209.6$ \\
\hline Bank of France 3/ & 01-Feb-2018 & 31-Dec-2024 & $2,000.0$ & - & - & - & - \\
\hline \multicolumn{8}{|l|}{ Germany } \\
\hline Kreditanstalt für Wiederaufbau & 31-Mar-1989 & 31-Dec-1997 & 700.0 & 700.0 & 100.0 & 19.7 & - \\
\hline Kreditanstalt für Wiederaufbau & 17-May-1995 & 31-Dec-2005 & 700.0 & 700.0 & 100.0 & 313.0 & - \\
\hline Kreditanstalt für Wiederaufbau 1/ & 19-Jun-2000 & 31-Dec-2014 & $1,350.0$ & $1,350.0$ & 100.0 & 591.0 & 287.8 \\
\hline Italy & & & & & & & \\
\hline Bank of Italy $7 /$ & 04-Oct-1990 & 31-Dec-1997 & 370.0 & 370.0 & 100.0 & 11.7 & - \\
\hline Bank of Italy $7 /$ & 29-May-1998 & 31-Dec-2005 & 210.0 & 210.0 & 100.0 & 170.9 & - \\
\hline Bank of Italy 1 / & 01-Mar-2000 & 31-Dec-2014 & 800.0 & 800.0 & 100.0 & 164.8 & 101.5 \\
\hline Bank of Italy 3 / & 18-Apr-2011 & 31-Dec-2024 & 800.0 & 726.8 & 90.8 & - & 686.0 \\
\hline Bank of Italy $3 /$ & $17-J u l-2017$ & 31-Dec-2024 & 400.0 & - & - & - & - \\
\hline Japan & & & & & & & \\
\hline Japan Bank for International Cooperation 8/ & 12-Apr-1988 & 31-Dec-1997 & $2,200.0$ & $2,200.0$ & 100.0 & - & - \\
\hline Japan Bank for International Cooperation 1/ 8/ & 05-Oct-1994 & 31-Dec-2014 & $2,934.8$ & $2,934.8$ & 100.0 & - & 65.4 \\
\hline Government of Japan 2/ & 03-Sep-2010 & 31-Dec-2024 & $1,800.0$ & 96.8 & 5.4 & - & 94.4 \\
\hline Government of Japan 2/ 4/ & 20-Apr-2017 & 31-Dec-2024 & $1,800.0$ & - & - & - & - \\
\hline Korea & & & & & & & \\
\hline Bank of Korea & 20-Apr-1989 & 31-Dec-1997 & 65.0 & 65.0 & 100.0 & 0.3 & - \\
\hline Bank of Korea & 20-Jun-1994 & 31-Dec-2005 & 27.7 & 27.7 & 100.0 & 20.0 & - \\
\hline Bank of Korea 2/ & 07-Jan-2011 & 31-Dec-2024 & 500.0 & 39.7 & 7.9 & - & 39.7 \\
\hline Bank of Korea 2/ 4/ & 20-Dec-2016 & 31-Dec-2024 & 500.0 & - & - & - & - \\
\hline Netherlands & & & & & & & \\
\hline Bank of the Netherlands $1 /$ & 29-Sep-1999 & 31-Dec-2014 & 450.0 & 450.0 & 100.0 & 55.2 & 60.1 \\
\hline Bank of the Netherlands 2/ & 27-Jul-2010 & 31-Dec-2024 & 500.0 & 8.4 & 1.7 & - & 8.4 \\
\hline Bank of the Netherlands 2/4/ & 20-Dec-2016 & 31-Dec-2024 & 500.0 & - & - & - & - \\
\hline Norway & & & & & & & \\
\hline Bank of Norway & 14-Apr-1988 & 31-Dec-1997 & 90.0 & 90.0 & 100.0 & 2.7 & - \\
\hline Bank of Norway & 16-Jun-1994 & 31-Dec-2005 & 60.0 & 60.0 & 100.0 & 32.5 & - \\
\hline Government of Norway 9/ & 25-Jun-2010 & 31-Dec-2024 & 300.0 & 300.0 & 100.0 & - & 229.0 \\
\hline Government of Norway 9/ & 17-Nov-2016 & 31-Dec-2024 & 300.0 & - & - & - & - \\
\hline
\end{tabular}




\begin{tabular}{|c|c|c|c|c|c|}
\hline \multicolumn{6}{|c|}{$\begin{array}{c}\text { Appendix Table 2. Bilateral Commitments to the PRGF-ESF and PRG-HIPC Trusts } \\
\text { (In millions of SDRs; as of end-December 2017) }\end{array}$} \\
\hline & \multicolumn{3}{|c|}{ PRGF-ESF Trust 2/ } & \multicolumn{2}{|c|}{ PRG-HIPC Trust } \\
\hline & \multicolumn{3}{|c|}{ Subsidy contributions } & \multirow{2}{*}{$\begin{array}{c}\text { Subsidies and HIPC } \\
\text { grant contributions 5/ }\end{array}$} & \multirow{2}{*}{$\begin{array}{l}\text { Of which } \\
\text { Pending }\end{array}$} \\
\hline & $\begin{array}{c}\text { For subsidization } \\
3 / \\
\end{array}$ & $\begin{array}{c}\text { For MDRI } \\
\text { debt relief 4/ }\end{array}$ & Total & & \\
\hline TOTAL & $2,191.9$ & $1,120.0$ & $3,311.9$ & $1,562.3$ & 25.9 \\
\hline Major industrial countries & $1,419.7$ & 818.8 & $2,238.5$ & 880.5 & -- \\
\hline Canada & 144.5 & 84.8 & 229.3 & 48.8 & -- \\
\hline France & 232.2 & 116.4 & 348.6 & 82.2 & -- \\
\hline Germany & 113.4 & 66.1 & 179.6 & 127.2 & -- \\
\hline Italy & 128.0 & 84.4 & 212.4 & 63.6 & -- \\
\hline Japan & 434.8 & 253.4 & 688.2 & 144.0 & -- \\
\hline United Kingdom & 266.7 & 155.4 & 422.1 & 82.2 & -- \\
\hline United States & 100.0 & 58.3 & 158.3 & 332.6 & -- \\
\hline Other advanced countries & 645.9 & 250.4 & 896.2 & 299.7 & -- \\
\hline Australia & 12.5 & 3.7 & 16.2 & 24.8 & -- \\
\hline Austria & 61.4 & -- & 61.4 & 14.3 & -- \\
\hline Belgium & 66.1 & 39.5 & 105.6 & 35.3 & -- \\
\hline Denmark & 40.5 & 23.6 & 64.1 & 18.5 & -- \\
\hline Finland & 26.0 & 15.1 & 41.1 & 8.0 & -- \\
\hline Greece & 22.9 & 13.3 & 36.2 & 6.3 & -- \\
\hline Iceland & 2.6 & 1.5 & 4.2 & 0.9 & -- \\
\hline Ireland & 5.4 & 2.4 & 7.7 & 5.9 & -- \\
\hline Israel & -- & -- & -- & 1.8 & -- \\
\hline Korea & 39.5 & 21.0 & 60.5 & 15.9 & -- \\
\hline Luxembourg & 12.9 & -- & 12.9 & 0.7 & -- \\
\hline Netherlands & 128.5 & -- & 128.5 & 45.4 & -- \\
\hline New Zealand & -- & -- & -- & 1.7 & -- \\
\hline Norway & 26.8 & 15.7 & 42.4 & 18.5 & -- \\
\hline Portugal & 2.6 & 1.4 & 4.0 & 6.6 & -- \\
\hline San Marino & -- & -- & -- & $0.0^{*}$ & -- \\
\hline Singapore & 11.1 & 6.5 & 17.6 & 16.5 & -- \\
\hline Spain & 12.9 & 3.1 & 16.1 & 23.3 & -- \\
\hline Sweden & 109.0 & 65.0 & 174.0 & 18.3 & -- \\
\hline Switzerland & 65.2 & 38.5 & 103.7 & 37.0 & -- \\
\hline Fuel exporting countries & 10.2 & 6.1 & 16.3 & 114.3 & 23.2 \\
\hline Algeria & -- & -- & -- & 5.5 & -- \\
\hline Bahrain & -- & -- & -- & 0.9 & 0.9 \\
\hline Brunei Darussalam & -- & -- & -- & 0.1 & -- \\
\hline Gabon & -- & -- & -- & 2.5 & 1.9 \\
\hline Iran, Islamic Republic of & 1.0 & 0.6 & 1.5 & 2.2 & -- \\
\hline Kuwait & -- & -- & -- & 3.1 & -- \\
\hline Libya & -- & -- & -- & 7.3 & -- \\
\hline Nigeria & -- & -- & -- & 13.9 & -- \\
\hline Oman & -- & -- & -- & 0.8 & -- \\
\hline Qatar & -- & -- & -- & 0.5 & -- \\
\hline Saudi Arabia & 9.2 & 5.5 & 14.7 & 53.5 & -- \\
\hline United Arab Emirates & -- & -- & -- & 3.8 & -- \\
\hline Venezuela & -- & -- & -- & 20.4 & 20.4 \\
\hline
\end{tabular}




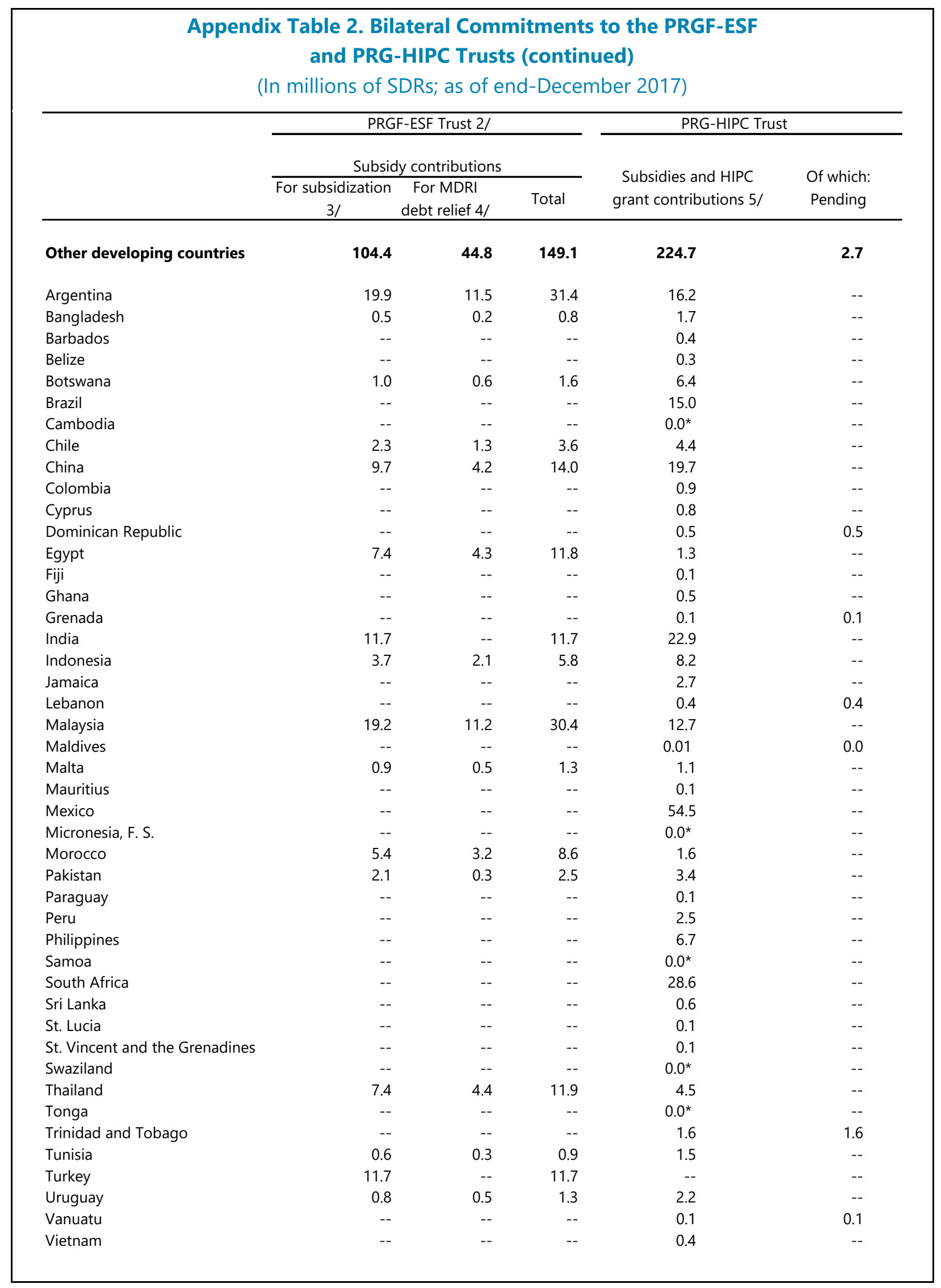




\begin{tabular}{|c|c|c|c|c|c|}
\hline \multicolumn{6}{|c|}{$\begin{array}{c}\text { Appendix Table 2. Bilateral Commitments to the PRGF-ESF } \\
\text { and PRG-HIPC Trusts (concluded) } \\
\text { (In millions of SDRs; as of end-December 2017) }\end{array}$} \\
\hline & \multicolumn{3}{|c|}{ PRGF-ESF Trust 2/ } & \multicolumn{2}{|c|}{ PRG-HIPC Trust } \\
\hline & \multicolumn{3}{|c|}{ Subsidy contributions } & \multirow{2}{*}{$\begin{array}{l}\text { Subsidies and HIPC } \\
\text { grant contributions 5/ }\end{array}$} & \multirow{2}{*}{$\begin{array}{l}\text { Of which: } \\
\text { Pending }\end{array}$} \\
\hline & $\begin{array}{c}\text { For } \\
\text { subsidization 3/ }\end{array}$ & $\begin{array}{c}\text { For MDRI } \\
\text { debt relief 4/ }\end{array}$ & Total & & \\
\hline Countries in transition & 11.8 & -- & 11.8 & 42.9 & -- \\
\hline Croatia & -- & -- & -- & 0.4 & -- \\
\hline Czech Republic & 11.8 & -- & 11.8 & 4.1 & -- \\
\hline Estonia & -- & -- & -- & 0.5 & -- \\
\hline Hungary & -- & -- & -- & 6.0 & -- \\
\hline Latvia & -- & -- & -- & 1.0 & -- \\
\hline Poland & -- & -- & -- & 12.0 & -- \\
\hline Russian Federation & -- & -- & -- & 14.6 & -- \\
\hline Slovak Republic & -- & -- & -- & 4.0 & -- \\
\hline Slovenia & -- & -- & -- & 0.4 & -- \\
\hline \multicolumn{6}{|c|}{$\begin{array}{l}\text { * Less than SDR 5,000. } \\
\text { 1/ Pre-2006 fund-raising initiatives. Subsidy contributions pledged before } 2006 \text { to the benefit of the PRGF Trust, the remainder of which is now } \\
\text { available for the PRGT, and for PRG-HIPC Trust. } \\
\text { 2/ Excludes SDR } 100 \text { million in end-2005 NPV terms committed by the G-8 to compensate for transfer from the PRGF Trust to the MDRI and } \\
\text { subsidy resources pledged and/or received under fundraising rounds since } 2006 \text {. } \\
\text { 3/ Estimated values of total contributions pledged before 2006. Amounts correspond to the nominal sum of contributions and earnings on } \\
\text { outstanding balances. } \\
\text { 4/ Amounts transferred in early } 2006 \text { from the PRGF Subsidy Accounts to the MDRI Trust. } \\
\text { 5/ Amounts reported on "as needed" basis, corresponding to the nominal sum of concessional assistance taking into account the profile of subsidy } \\
\text { needs associated with PRGF lending and the provision of HIPC assistance, respectively. Estimates were made at end-1999 in the context of HIPC } \\
\text { fundraising based on members' pledges. }\end{array}$} \\
\hline
\end{tabular}




\begin{tabular}{|c|c|c|c|c|c|}
\hline \multicolumn{6}{|c|}{$\begin{array}{l}\text { Appendix Table } 3 \text {. ESF Subsidy Contributions }{ }^{\mathbf{1 /}} \\
\text { (In millions of currency units; as of end-December 2017) }\end{array}$} \\
\hline & \multirow{2}{*}{ Form of contribution } & \multicolumn{3}{|c|}{ Contribution pledged } & \multirow{2}{*}{$\frac{\text { Contribution received }}{\text { (SDR equivalent) }}$} \\
\hline & & (Am & nount) & (SDR equivalent) & \\
\hline Canada & Grant & CAN\$ & 25.0 & 14.3 & 15.0 \\
\hline France & Concessional loan & SDR & $20.02 /$ & $20.02 /$ & 2.2 4/ \\
\hline Iceland & Grant & ISK & 10.2 & 0.1 & 0.1 \\
\hline Japan & Grant & SDR & 20.0 & 20.0 & 20.0 \\
\hline Norway & Grant & SDR & 24.7 & 24.7 & 24.7 \\
\hline Oman & Grant & SDR & 3.0 & 3.0 & 2.2 \\
\hline Russian Federation & Grant & SDR & 30.0 & 30.0 & 30.0 \\
\hline Saudi Arabia & Investment agreement & SDR & $40.03 /$ & $40.03 /$ & 6.4 4/ \\
\hline Spain & Grant & SDR & 5.3 & 5.3 & 5.3 \\
\hline Trinidad and Tobago & Deposit agreement & SDR & $0.83 /$ & $0.83 /$ & $0.24 / 5 /$ \\
\hline \multirow[t]{4}{*}{ United Kingdom } & Grant & $£$ & 50.0 & 53.1 & 53.1 \\
\hline & Total Grant & & & 150.5 & 150.4 \\
\hline & Total Implicit Subsidy & & & 20.0 & 2.2 \\
\hline & Total Investment and Deposit & & & 40.8 & 6.6 \\
\hline Total & & & & 211.3 & 159.1 \\
\hline $\begin{array}{l}\text { 1/ } 2005 \text { Exogenous Shocks } \\
\text { 2/ To be generated as an im } \\
\text { 3/ Reflecting net investment } \\
\text { 4/ Contributions received/g } \\
\text { 5/ Trinidad and Tobago's de }\end{array}$ & $\begin{array}{l}\text { cility (ESF) fundraising campaign. } \\
\text { licit subsidy from the concessional loar } \\
\text { ncome (in end- } 2005 \text { NPV terms) to be } \\
\text { erated in end- } 2005 \text { NPV terms. } \\
\text { osit matured on September } 18,2017 \text { a }\end{array}$ & $\begin{array}{l}\text { at } 0.5 \text { per } \\
\text { generated } \\
\text { nd was rep }\end{array}$ & $\begin{array}{l}\text { ercent or less } \\
\text { d from depos } \\
\text { paid before }\end{array}$ & it/investment agreem & unt of contribution. \\
\hline
\end{tabular}


Appendix Table 4. Pledges and Contributions of Bilateral Subsidy Resources for the PRGT

(In millions of SDR unless otherwise indicated; as of end-February 2018)

\begin{tabular}{|c|c|c|c|c|c|c|c|}
\hline & \multicolumn{5}{|c|}{ Under the 2009 LIC Financing Package 1/ } & \multirow{3}{*}{$\begin{array}{c}\text { Contributions upon } \\
\text { termination of the } \\
\text { EPCA/ENDA } \\
\text { subsidy account 2/ } \\
\text { SDR million } \\
\end{array}$} & \multirow{3}{*}{$\begin{array}{c}\begin{array}{c}\text { Total } \\
\text { Contributions } \\
\text { Received }\end{array} \\
\text { SDR million } \\
\end{array}$} \\
\hline & \multirow{2}{*}{ Form of contribution } & \multicolumn{3}{|c|}{ Contributions pledged } & $\begin{array}{l}\text { Contributions } \\
\text { received }\end{array}$ & & \\
\hline & & in millions of currency units & SDR equivaler & & SDR million & & \\
\hline Algeria & Grant & SDR 2.3 & 2.30 & & 2.30 & - & 2.30 \\
\hline Argentina & Grant & SDR 3.9 & 3.90 & & 3.90 & - & 3.90 \\
\hline Australia & Grant & $A \$ 30.0$ & 17.63 & & 17.63 & 0.06 & 17.69 \\
\hline Austria & Grant & SDR 3.9 & 3.90 & & 3.90 & 0.04 & 3.94 \\
\hline Belgium & - & - & - & & - & 0.23 & 0.23 \\
\hline Botswana & Investment & SDR 0.2 & 0.20 & $3 /$ & $0.03 \quad 4 /$ & - & 0.03 \\
\hline Canada & Grant & CAN $\$ 40$ and SDR 2.8 & 27.96 & & 27.96 & 0.77 & 28.73 \\
\hline China & Investment & SDR 17.5 & 17.50 & $3 /$ & $3.14 \quad 4 /$ & 0.08 & 3.22 \\
\hline Denmark & Grant & DKK 30.0 & 3.57 & & 3.57 & - & 3.57 \\
\hline Indonesia & Deposit & - & - & & 0.24 & - & - \\
\hline Italy & Grant & SDR 22.1 & 22.10 & & 22.10 & - & 22.10 \\
\hline Ireland & - & - & - & & - & 0.03 & 0.03 \\
\hline Japan & Grant & SDR 28.8 & 28.80 & & 28.80 & - & 28.80 \\
\hline Korea & Grant & SDR 8.8 & 8.80 & & 8.80 & 0.20 & 9.00 \\
\hline Kuwait & Grant & US\$3.9 & 2.61 & & 2.61 & - & 2.61 \\
\hline Luxembourg & - & - & - & & - & 0.28 & 0.28 \\
\hline Malta & Grant & SDR 0.2 & 0.20 & & 0.20 & - & 0.20 \\
\hline Morocco & Investment & SDR 1.1 & 1.10 & $3 /$ & $0.22 \quad 4 /$ & - & 0.22 \\
\hline Netherlands & Grant & SDR 9.5 & 9.50 & 5/ & 10.33 & 1.25 & 11.58 \\
\hline Peru & Investment & SDR 1.2 & 1.20 & $3 /$ & $0.354 /$ & - & 0.35 \\
\hline Philippines & Grant & SDR 1.9 & 1.90 & & 1.90 & - & 1.90 \\
\hline Qatar & Grant & SDR 0.6 & 0.60 & & 0.60 & - & 0.60 \\
\hline Saudi Arabia & Grant & SDR 11.0 & 11.00 & $6 /$ & - & 0.15 & 0.15 \\
\hline South Africa & TBD & SDR 3.4 & 3.40 & & - & - & - \\
\hline Spain & Grant & SDR 9.0 & 9.00 & & 8.82 & - & 8.82 \\
\hline Sweden & Grant & SEK 50.0 & 4.81 & & 4.77 & 3.15 & 7.92 \\
\hline Switzerland & Grant & CHF 16.0 & 11.11 & & 11.11 & 0.36 & 11.47 \\
\hline Trinidad and Tobago & TBD & SDR 0.6 & 0.60 & & - & - & - \\
\hline United Kingdom & Grant & SDR 19.8 & 19.80 & & 21.34 & 1.60 & 22.94 \\
\hline \multirow[t]{3}{*}{ Uruguay } & Investment & SDR 0.6 & 0.60 & $3 /$ & $0.12 \quad 4 /$ & - & 0.12 \\
\hline & Total Investment & & 20.6 & & 3.8 & & \\
\hline & Total Grants and other & & 193.5 & & 180.9 & & \\
\hline Total & & & 214.1 & & 184.7 & 8.2 & 192.7 \\
\hline $\begin{array}{l}\text { 1/ } 2009 \text { LIC fundraising } \\
\text { 2/ Transfer of member } \\
\text { (see Update on the Fin } \\
\text { 3/ Reflecting net inves } \\
\text { 4/ Reflecting end-Dece } \\
\text { 5/ Initial pledge of SDF } \\
\text { 6/ A pledge of SDR 16, } \\
11 \text { million in end 2008 }\end{array}$ & $\begin{array}{l}\text { campaign. } \\
s^{\prime} \text { share in the balance } \\
\text { ancing of the Fund's C } \\
\text { ment income (in end- } 2 \\
\text { mber } 2017 \text { net income } \\
9.5 \text { million has been c } \\
709,643 \text { is to be receive } \\
\text { NPV terms at the time }\end{array}$ & $\begin{array}{l}\text { f EPCA/ENDA Administered } \\
\text { ncessional Assistance and P } \\
008 \text { NPV terms) to be gener } \\
\text { earned on the investment (i } \\
\text { hanged to SDR } 10.33 \text { million } \\
\text { d following expiry of existin } \\
\text { when the pledge was made. }\end{array}$ & $\begin{array}{l}\text { ubsidy Accour } \\
\text { posed Amend } \\
\text { ed from inves } \\
\text { end-2008 NPV } \\
\text { ast payment re } \\
\text { investment ag }\end{array}$ & $\begin{array}{l}\text { nt u } \\
\text { dme } \\
\text { tme } \\
\text { V ter } \\
\text { ecei } \\
\text { greer }\end{array}$ & $\begin{array}{l}\text { on the Accoun } \\
\text { ts to the PRGT } \\
\text { t agreements. } \\
\text { ns). } \\
\text { ed in February } \\
\text { ent with the P }\end{array}$ & $\begin{array}{l}\text { 's Termination on Fe } \\
\text { Instrument, April 8, } \\
2018 \text {. } \\
\text { GT on } 12 / 31 / 2021 \text {; }\end{array}$ & $\begin{array}{l}\text { bruary 1, } 2014 \\
\text { 014). }\end{array}$ \\
\hline
\end{tabular}




\begin{tabular}{|c|c|c|c|c|c|c|}
\hline \multicolumn{7}{|c|}{$\begin{array}{c}\text { Appendix Table 5. Distribution of the General Reserve } \\
\text { Associated with Gold Windfall Profits 1/2/ } \\
\text { (As of end-February } 2018 \text { ) }\end{array}$} \\
\hline \multirow{3}{*}{ Member } & \multicolumn{3}{|c|}{ Distribution of SDR 700 Million 3/ } & \multicolumn{3}{|c|}{ Distribution of SDR 1,750 Million 4/ } \\
\hline & Pledges & $\begin{array}{c}\text { Payment/Transfer } \\
\text { Amount } \\
\end{array}$ & \multirow[t]{2}{*}{$\begin{array}{c}\text { Date of Transfer/Equivalent } \\
\text { Bilateral Contribution }\end{array}$} & Pledges & $\begin{array}{c}\text { Payment/Transfer } \\
\text { Amount } \\
\end{array}$ & \multirow[t]{2}{*}{$\begin{array}{c}\text { Date of Transfer/Equivalent } \\
\text { Bilateral Contribution }\end{array}$} \\
\hline & \multicolumn{2}{|c|}{ (In millions of SDRs) } & & \multicolumn{2}{|c|}{ (In millions of SDRs) } & \\
\hline Afghanistan & - & - & - & 1.19 & 1.19 & $10 / 22 / 2013$ \\
\hline Albania & - & - & - & 0.44 & 0.44 & $10 / 22 / 2013$ \\
\hline Algeria & 3.69 & 3.69 & $10 / 23 / 2012$ & 9.22 & 9.22 & $10 / 22 / 2013$ \\
\hline Angola & - & - & - & 2.10 & 2.10 & $10 / 22 / 2013$ \\
\hline Antigua and Barbuda & - & - & - & 0.10 & 0.10 & $10 / 22 / 2013$ \\
\hline Argentina & 6.22 & 6.22 & $10 / 23 / 2012$ & 15.56 & 15.56 & $10 / 22 / 2013$ \\
\hline Armenia & 0.27 & 0.27 & $10 / 23 / 2012$ & 0.68 & 0.68 & $10 / 22 / 2013$ \\
\hline Australia 5/ & 9.51 & 9.55 & $4 / 26 / 2013$ & 23.79 & 23.28 & $7 / 23 / 2014$ \\
\hline Austria & 6.21 & 6.21 & $10 / 25 / 2013$ & 15.54 & 15.54 & $10 / 25 / 2013$ \\
\hline Azerbaijan & - & - & - & 1.18 & - & pending \\
\hline Bahamas, The & - & - & - & 0.96 & 0.96 & $10 / 22 / 2013$ \\
\hline Bahrain & - & - & - & 0.99 & - & pending \\
\hline Bangladesh & 1.57 & 1.57 & $10 / 23 / 2012$ & 3.92 & 3.92 & $10 / 22 / 2013$ \\
\hline Barbados & - & - & - & 0.50 & 0.50 & $10 / 22 / 2013$ \\
\hline Belarus & 1.14 & 1.14 & $10 / 23 / 2012$ & 2.84 & 2.84 & $10 / 22 / 2013$ \\
\hline Belgium 5/ & 10.15 & 10.11 & $8 / 28 / 2014$ & 25.38 & 25.48 & $12 / 28 / 2015$ \\
\hline Belize & 0.06 & 0.06 & $10 / 26 / 2012$ & 0.14 & 0.14 & $10 / 22 / 2013$ \\
\hline Benin & 0.18 & 0.18 & $10 / 23 / 2012$ & 0.45 & 0.45 & $10 / 22 / 2013$ \\
\hline Bhutan & 0.02 & 0.02 & $10 / 23 / 2012$ & 0.05 & 0.05 & $10 / 22 / 2013$ \\
\hline Bolivia & - & - & - & - & - & - \\
\hline Bosnia & 0.50 & 0.50 & $10 / 23 / 2012$ & 1.24 & 1.24 & $10 / 22 / 2013$ \\
\hline Botswana & 0.23 & 0.23 & $10 / 23 / 2012$ & 0.58 & 0.58 & $10 / 22 / 2013$ \\
\hline Brazil & 12.50 & - & pending & 31.24 & - & pending \\
\hline Brunei & 0.63 & 0.63 & $10 / 23 / 2012$ & 1.58 & 1.58 & $10 / 22 / 2013$ \\
\hline Bulgaria & 1.69 & 1.69 & $10 / 23 / 2012$ & 4.23 & 4.23 & $10 / 22 / 2013$ \\
\hline Burkina Faso & 0.18 & 0.18 & $10 / 23 / 2012$ & 0.44 & 0.44 & $10 / 22 / 2013$ \\
\hline Burundi & 0.20 & 0.20 & $10 / 23 / 2012$ & 0.57 & 0.57 & $10 / 22 / 2013$ \\
\hline Cambodia & 0.26 & 0.26 & $10 / 23 / 2012$ & 0.64 & 0.64 & $10 / 22 / 2013$ \\
\hline Cameroon & 0.55 & 0.55 & $10 / 23 / 2012$ & 1.36 & 1.36 & $10 / 22 / 2013$ \\
\hline Canada & 18.72 & 18.72 & $10 / 23 / 2012$ & 46.81 & 46.81 & $10 / 22 / 2013$ \\
\hline Cape Verde & 0.03 & 0.03 & $10 / 23 / 2012$ & - & - & - \\
\hline Central African Republic & 0.16 & 0.16 & $10 / 23 / 2012$ & - & - & - \\
\hline Chad & 0.20 & 0.20 & $10 / 23 / 2012$ & 0.49 & 0.49 & $10 / 22 / 2013$ \\
\hline Chile & - & - & - & - & - & - \\
\hline China & 28.00 & 28.00 & $10 / 23 / 2012$ & 70.01 & 70.01 & $10 / 22 / 2013$ \\
\hline Colombia & - & - & - & 5.57 & - & pending \\
\hline Comoros & 0.03 & 0.03 & $10 / 23 / 2012$ & 0.07 & 0.07 & $10 / 22 / 2013$ \\
\hline Congo, Democratic Republic of the & 1.57 & 1.57 & $10 / 23 / 2012$ & 3.92 & 3.92 & $10 / 22 / 2013$ \\
\hline Congo, Republic of & - & - & - & 0.62 & 0.62 & $10 / 22 / 2013$ \\
\hline Costa Rica & 0.48 & - & pending & 1.21 & - & pending \\
\hline Cote d'Ivoire & 0.96 & 0.96 & $10 / 23 / 2012$ & 2.39 & 2.39 & $10 / 22 / 2013$ \\
\hline Croatia & 0.54 & 0.54 & $11 / 5 / 2013$ & 1.34 & 1.34 & $11 / 5 / 2013$ \\
\hline Cyprus & 0.47 & 0.47 & $3 / 28 / 2016$ & 1.16 & 1.16 & $3 / 28 / 2016$ \\
\hline Czech Republic 6/ & 2.95 & 2.95 & $11 / 26 / 2012$ & 7.37 & 7.37 & $10 / 22 / 2013$ \\
\hline Denmark & 5.56 & 5.56 & $12 / 18 / 2013$ & 13.90 & 13.85 & $12 / 4 / 2014$ \\
\hline Djibouti & 0.05 & 0.05 & $10 / 23 / 2012$ & 0.12 & 0.12 & $10 / 22 / 2013$ \\
\hline Dominica & 0.02 & 0.02 & $10 / 23 / 2012$ & 0.06 & 0.06 & $10 / 22 / 2013$ \\
\hline Dominican Republic & - & - & - & - & - & - \\
\hline Ecuador & - & - & - & - & - & - \\
\hline Egypt & 2.77 & 2.77 & $10 / 23 / 2012$ & 6.94 & 6.94 & $10 / 22 / 2013$ \\
\hline El Salvador & - & - & - & - & - & - \\
\hline Equatorial Guinea & - & - & - & 0.38 & - & pending \\
\hline Eritrea & - & - & - & - & - & - \\
\hline Estonia & 0.28 & 0.28 & $10 / 23 / 2012$ & 0.69 & 0.69 & $10 / 22 / 2013$ \\
\hline Ethiopia & 0.39 & 0.39 & $10 / 23 / 2012$ & 0.98 & 0.98 & $10 / 22 / 2013$ \\
\hline Fiji & 0.21 & 0.21 & $10 / 23 / 2012$ & 0.52 & 0.52 & $10 / 22 / 2013$ \\
\hline Finland & 3.72 & 3.72 & $10 / 23 / 2012$ & 9.29 & 9.29 & $10 / 22 / 2013$ \\
\hline France & 31.57 & 31.57 & $10 / 23 / 2012$ & 78.92 & 78.92 & $10 / 22 / 2013$ \\
\hline Gabon & 0.45 & 0.45 & $10 / 23 / 2012$ & 1.13 & 1.13 & $10 / 22 / 2013$ \\
\hline
\end{tabular}




\begin{tabular}{|c|c|c|c|c|c|c|}
\hline \multicolumn{7}{|c|}{$\begin{array}{l}\text { Appendix Table 5. Distribution of the General Reserve } \\
\text { Associated with Gold Windfall Profits (continued) } \\
\text { (As of end-February 2018) }\end{array}$} \\
\hline \multirow{3}{*}{ Member } & \multicolumn{3}{|c|}{ Distribution of SDR 700 Million 3/ } & \multicolumn{3}{|c|}{ Distribution of SDR 1,750 Million 4/ } \\
\hline & Pledges & $\begin{array}{c}\text { Payment/Transfer } \\
\text { Amount } \\
\end{array}$ & \multirow[t]{2}{*}{$\begin{array}{l}\text { Date of Transfer/Equivalent } \\
\text { Bilateral Contribution }\end{array}$} & Pledges & $\begin{array}{c}\text { Payment/Transfer } \\
\text { Amount } \\
\end{array}$ & \multirow[t]{2}{*}{$\begin{array}{l}\text { Date of Transfer/Equivalent } \\
\text { Bilateral Contribution }\end{array}$} \\
\hline & \multicolumn{2}{|c|}{ (In millions of SDRs) } & & \multicolumn{2}{|c|}{ (In millions of SDRs) } & \\
\hline Gambia, The & 0.09 & 0.09 & $10 / 23 / 2012$ & 0.23 & 0.23 & $10 / 22 / 2013$ \\
\hline Georgia & 0.44 & 0.44 & 10/23/2012 & 1.10 & 1.10 & $10 / 22 / 2013$ \\
\hline Germany & 42.82 & 42.82 & $12 / 6 / 2012$ & 107.05 & 107.05 & $10 / 24 / 2013$ \\
\hline Ghana 6/ & 1.08 & 1.08 & $11 / 8 / 2012$ & 2.71 & - & pending \\
\hline Greece & 3.24 & 3.24 & 10/23/2012 & 8.10 & 8.10 & $10 / 22 / 2013$ \\
\hline Grenada & 0.03 & - & pending & - & - & - \\
\hline Guatemala & - & - & - & - & - & - \\
\hline Guinea & 0.31 & 0.31 & $10 / 23 / 2012$ & 0.79 & 0.79 & $10 / 22 / 2013$ \\
\hline Guinea-Bissau & 0.04 & 0.04 & $10 / 23 / 2012$ & 0.10 & 0.10 & $10 / 22 / 2013$ \\
\hline Guyana & - & - & - & - & - & - \\
\hline Haiti & 0.24 & 0.24 & $10 / 23 / 2012$ & 0.60 & 0.60 & $10 / 22 / 2013$ \\
\hline Honduras & 0.38 & 0.38 & 10/23/2012 & 0.95 & 0.95 & $10 / 22 / 2013$ \\
\hline Hungary & 3.05 & - & pending & 7.63 & - & pending \\
\hline Iceland 6/ & 0.35 & 0.35 & $3 / 24 / 2014$ & 0.86 & 0.86 & $2 / 24 / 2014$ \\
\hline India & 17.11 & 17.11 & 10/23/2012 & 42.78 & 42.78 & $10 / 22 / 2013$ \\
\hline Indonesia & 6.11 & - & pending & 15.28 & - & pending \\
\hline Iran, Islamic Republic of 5/ & 4.40 & 4.40 & 9/8/2015 & 11.00 & 11.00 & 9/8/2015 \\
\hline Iraq & 3.49 & 3.49 & $10 / 23 / 2012$ & - & - & - \\
\hline Ireland & 3.70 & 3.72 & $11 / 8 / 2017$ & 9.24 & 9.30 & $11 / 8 / 2017$ \\
\hline Israel & - & - & - & - & - & - \\
\hline Italy & 23.17 & 23.17 & $10 / 23 / 2012$ & 57.93 & 57.93 & $10 / 22 / 2013$ \\
\hline Jamaica & 0.80 & 0.80 & 10/23/2012 & 2.01 & 2.01 & $10 / 22 / 2013$ \\
\hline Japan 5/ & 45.94 & 38.09 & $3 / 11 / 2013$ & 114.86 & 110.55 & $3 / 4 / 2014$ \\
\hline Jordan 5/ & 0.50 & 0.50 & $10 / 23 / 2012$ & 1.25 & 1.25 & $7 / 16 / 2015$ \\
\hline Kazakhstan & - & - & - & - & - & - \\
\hline Kenya & 0.80 & 0.80 & $10 / 23 / 2012$ & 1.99 & 1.99 & $4 / 7 / 2014$ \\
\hline Kiribati & - & - & - & - & - & - \\
\hline Korea 6/ & 9.90 & 9.90 & $1 / 24 / 2013$ & 24.74 & 24.76 & 9/18/2014 \\
\hline Kosovo & - & - & - & 0.43 & 0.43 & $10 / 22 / 2013$ \\
\hline Kuwait & 4.06 & 4.06 & $10 / 23 / 2012$ & 10.15 & 10.15 & $10 / 22 / 2013$ \\
\hline Kyrgyz Republic & 0.26 & 0.26 & $10 / 23 / 2012$ & 0.65 & 0.65 & $10 / 22 / 2013$ \\
\hline Lao P.D.R. 6/ & 0.16 & 0.16 & $11 / 20 / 2012$ & 0.39 & 0.39 & $10 / 22 / 2013$ \\
\hline Latvia & 0.42 & 0.42 & $12 / 20 / 2012$ & 1.04 & 1.04 & $12 / 20 / 2013$ \\
\hline Lebanon & 0.78 & - & pending & 1.96 & - & pending \\
\hline Lesotho & 0.05 & 0.05 & $10 / 23 / 2012$ & 0.26 & 0.26 & $10 / 22 / 2013$ \\
\hline Liberia & 0.38 & 0.38 & $10 / 23 / 2012$ & - & - & - \\
\hline Libya & 3.30 & - & pending & 8.26 & - & pending \\
\hline Lithuania & 0.54 & 0.54 & $10 / 23 / 2012$ & 1.35 & 1.35 & $10 / 22 / 2013$ \\
\hline Luxembourg & 1.23 & 1.23 & $10 / 24 / 2012$ & 3.08 & 3.08 & $10 / 22 / 2013$ \\
\hline Macedonia, FYR & 0.20 & 0.20 & $10 / 23 / 2012$ & 0.51 & 0.51 & $10 / 22 / 2013$ \\
\hline Madagascar 2/ & - & - & - & - & - & - \\
\hline Malawi & 0.18 & 0.18 & $10 / 23 / 2012$ & 0.51 & 0.51 & $10 / 22 / 2013$ \\
\hline Malaysia & 5.21 & 5.21 & $10 / 23 / 2012$ & 13.04 & 13.04 & $10 / 22 / 2013$ \\
\hline Maldives & 0.03 & 0.03 & $10 / 23 / 2012$ & 0.07 & 0.07 & $10 / 22 / 2013$ \\
\hline Mali & 0.27 & 0.27 & $10 / 23 / 2012$ & 0.69 & 0.69 & $10 / 22 / 2013$ \\
\hline Malta & 0.30 & 0.30 & 10/23/2012 & 0.75 & 0.75 & $10 / 22 / 2013$ \\
\hline Marshall Islands & - & - & - & - & - & - \\
\hline Mauritania & 0.19 & 0.19 & $10 / 23 / 2012$ & 0.47 & 0.47 & $10 / 22 / 2013$ \\
\hline Mauritius & 0.30 & 0.30 & $10 / 23 / 2012$ & 0.75 & 0.75 & $11 / 7 / 2013$ \\
\hline Mexico 5/ & 10.66 & 10.66 & $7 / 23 / 2015$ & 26.65 & 26.65 & $7 / 23 / 2015$ \\
\hline Micronesia & - & - & - & 0.04 & 0.04 & $10 / 22 / 2013$ \\
\hline Moldova & 0.36 & 0.36 & $10 / 23 / 2012$ & 0.91 & 0.91 & $10 / 22 / 2013$ \\
\hline Mongolia & 0.15 & 0.15 & $10 / 23 / 2012$ & 0.38 & 0.38 & $10 / 22 / 2013$ \\
\hline Montenegro & 0.04 & 0.04 & $11 / 26 / 2012$ & 0.10 & 0.10 & $10 / 31 / 2013$ \\
\hline Morocco & 1.73 & 1.73 & $10 / 23 / 2012$ & 4.32 & 4.32 & $10 / 22 / 2013$ \\
\hline Mozambique & 0.33 & 0.33 & $10 / 23 / 2012$ & 0.83 & 0.83 & $10 / 22 / 2013$ \\
\hline Myanmar & 0.76 & 0.76 & 10/23/2012 & 1.90 & 1.90 & $10 / 22 / 2013$ \\
\hline Namibia & 0.40 & 0.40 & $10 / 23 / 2012$ & 1.00 & 1.00 & $10 / 22 / 2013$ \\
\hline Nepal 6/ & 0.21 & 0.21 & $2 / 13 / 2013$ & 0.52 & 0.52 & $10 / 22 / 2013$ \\
\hline
\end{tabular}




\begin{tabular}{|c|c|c|c|c|c|c|}
\hline \multicolumn{7}{|c|}{$\begin{array}{c}\text { Appendix Table 5. Distribution of the General Reserve } \\
\text { Associated with Gold Windfall Profits (continued) } \\
\text { (As of end-February } 2018 \text { ) }\end{array}$} \\
\hline \multirow{3}{*}{ Member } & \multicolumn{3}{|c|}{ Distribution of SDR 700 Million 3/ } & \multicolumn{3}{|c|}{ Distribution of SDR 1,750 Million 4/ } \\
\hline & Pledges & $\begin{array}{c}\text { Payment/Transfer } \\
\text { Amount } \\
\end{array}$ & \multirow[t]{2}{*}{$\begin{array}{c}\text { Date of Transfer/Equivalent } \\
\text { Bilateral Contribution }\end{array}$} & Pledges & $\begin{array}{c}\text { Payment/Transfer } \\
\text { Amount } \\
\end{array}$ & \multirow[t]{2}{*}{$\begin{array}{l}\text { Date of Transfer/Equivalent } \\
\text { Bilateral Contribution }\end{array}$} \\
\hline & $(\operatorname{In~} \mathrm{mi}$ & illions of SDRs) & & $(\ln \mathrm{mi}$ & Ilions of SDRs) & \\
\hline Netherlands & 15.18 & 15.18 & $10 / 23 / 2012$ & 37.94 & 37.94 & $10 / 22 / 2013$ \\
\hline New Zealand & 2.63 & 2.63 & $10 / 23 / 2012$ & 6.57 & 6.57 & $10 / 22 / 2013$ \\
\hline Nicaragua & 0.38 & 0.38 & $10 / 23 / 2012$ & 0.96 & 0.96 & $10 / 22 / 2013$ \\
\hline Niger & 0.19 & 0.19 & $10 / 23 / 2012$ & 0.48 & 0.48 & $10 / 22 / 2013$ \\
\hline Nigeria & 5.15 & 5.15 & $10 / 23 / 2012$ & 12.88 & 12.88 & $10 / 22 / 2013$ \\
\hline Norway & 5.54 & 5.54 & $12 / 6 / 2013$ & 13.84 & 13.84 & $12 / 6 / 2013$ \\
\hline Oman & 0.70 & 0.70 & $11 / 13 / 2013$ & 1.74 & 1.74 & $10 / 22 / 2013$ \\
\hline Pakistan & 3.04 & 3.04 & $10 / 23 / 2012$ & 7.60 & 7.60 & $10 / 22 / 2013$ \\
\hline Palau & - & - & - & - & - & - \\
\hline Panama & 0.61 & 0.61 & $10 / 23 / 2012$ & 1.52 & 1.52 & $10 / 22 / 2013$ \\
\hline Papua New Guinea & 0.39 & 0.39 & $10 / 23 / 2012$ & 0.97 & - & pending \\
\hline Paraguay & 0.29 & 0.29 & $10 / 7 / 2014$ & 0.73 & 0.73 & $10 / 7 / 2014$ \\
\hline Peru & 1.88 & - & pending & 4.69 & - & pending \\
\hline Philippines & 3.00 & 3.00 & $10 / 23 / 2012$ & - & - & - \\
\hline Poland & 4.96 & - & pending & 12.41 & - & pending \\
\hline Portugal & 3.03 & 3.03 & $10 / 23 / 2012$ & 7.57 & 7.57 & $10 / 22 / 2013$ \\
\hline Qatar & 0.89 & 0.89 & $10 / 23 / 2012$ & 2.22 & - & pending \\
\hline Romania 6/ & - & - & - & 7.57 & 7.58 & $12 / 18 / 2015$ \\
\hline Russia 6/ & 17.48 & 17.49 & $10 / 10 / 2013$ & 43.69 & 43.69 & $10 / 22 / 2013$ \\
\hline Rwanda & 0.24 & 0.24 & $10 / 23 / 2012$ & 0.59 & 0.59 & $10 / 22 / 2013$ \\
\hline Samoa & - & - & - & 0.09 & 0.09 & $10 / 22 / 2013$ \\
\hline San Marino & 0.07 & 0.07 & $10 / 23 / 2012$ & 0.08 & 0.08 & $10 / 22 / 2013$ \\
\hline Sao Tome & 0.02 & 0.02 & $10 / 23 / 2012$ & 0.05 & 0.05 & $10 / 22 / 2013$ \\
\hline Saudi Arabia & 20.54 & 20.54 & $10 / 23 / 2012$ & 51.34 & 51.34 & $10 / 22 / 2013$ \\
\hline Senegal & 0.48 & 0.48 & $10 / 23 / 2012$ & 1.19 & 1.19 & $10 / 22 / 2013$ \\
\hline Serbia, Republic of & 1.37 & 1.37 & $10 / 23 / 2012$ & 3.44 & 3.44 & $10 / 22 / 2013$ \\
\hline Seychelles & 0.03 & 0.03 & $10 / 23 / 2012$ & 0.08 & 0.08 & $10 / 22 / 2013$ \\
\hline Sierra Leone & 0.30 & 0.30 & $10 / 23 / 2012$ & 0.76 & 0.76 & $10 / 22 / 2013$ \\
\hline Singapore & 4.14 & 4.14 & $2 / 15 / 2017$ & 10.35 & 10.37 & $2 / 1 / 2017$ \\
\hline Slovak Republic 5/ & 1.13 & 1.13 & $12 / 14 / 2012$ & 2.83 & 2.83 & $12 / 4 / 2013$ \\
\hline Slovenia & 0.40 & 0.40 & $12 / 4 / 2012$ & 1.01 & 1.01 & $10 / 25 / 2013$ \\
\hline Solomon Islands & 0.03 & 0.03 & $10 / 23 / 2012$ & 0.08 & 0.08 & $10 / 22 / 2013$ \\
\hline Somalia 2/ & - & - & - & - & - & - \\
\hline South Africa & 5.49 & 5.53 & $8 / 31 / 2017$ & 13.73 & 13.79 & $5 / 22 / 2017$ \\
\hline South Sudan & - & - & - & - & - & - \\
\hline Spain & 11.83 & 11.83 & $10 / 23 / 2012$ & 29.57 & 29.57 & $10 / 22 / 2013$ \\
\hline Sri Lanka 6/ & 1.22 & 1.22 & $2 / 1 / 2013$ & 3.04 & 3.04 & $10 / 22 / 2013$ \\
\hline St. Kitts & - & - & - & - & - & - \\
\hline St. Lucia & - & - & - & 0.11 & 0.11 & $10 / 22 / 2013$ \\
\hline St. Vincent and Grenadines & - & - & - & - & - & - \\
\hline Sudan 2/ & - & - & - & - & - & - \\
\hline Suriname & - & - & - & - & - & - \\
\hline Swaziland & - & - & - & - & - & - \\
\hline Sweden 6/ & 7.04 & 7.04 & $11 / 19 / 2012$ & 17.61 & 17.61 & $10 / 22 / 2013$ \\
\hline Switzerland 5/ 7/ & 10.17 & 10.17 & $1 / 23 / 2015$ & 25.42 & 27.04 & $1 / 24 / 2018$ \\
\hline Syria & - & - & - & - & - & - \\
\hline Tajikistan & 0.26 & 0.26 & $10 / 23 / 2012$ & 0.64 & 0.64 & $10 / 22 / 2013$ \\
\hline Tanzania & 0.58 & 0.58 & $10 / 23 / 2012$ & 1.46 & 1.46 & $10 / 22 / 2013$ \\
\hline Thailand & 4.23 & 4.23 & $10 / 23 / 2012$ & 10.59 & 10.59 & $10 / 22 / 2013$ \\
\hline Timor-Leste & - & - & - & 0.06 & 0.06 & $10 / 22 / 2013$ \\
\hline Togo & 0.22 & 0.22 & $10 / 23 / 2012$ & 0.54 & 0.54 & $10 / 22 / 2013$ \\
\hline Tonga & 0.02 & 0.02 & $10 / 23 / 2012$ & 0.05 & 0.05 & $10 / 22 / 2013$ \\
\hline Trinidad and Tobago & 0.99 & 0.99 & $10 / 23 / 2012$ & - & - & - \\
\hline Tunisia & 0.84 & 0.84 & $10 / 23 / 2012$ & 2.11 & 2.11 & $10 / 22 / 2013$ \\
\hline Turkey 5/ & 4.28 & 4.27 & $4 / 5 / 2013$ & 10.70 & 10.70 & $12 / 9 / 2015$ \\
\hline Turkmenistan & 0.22 & 0.22 & $10 / 23 / 2012$ & 0.55 & 0.55 & $10 / 22 / 2013$ \\
\hline Tuvalu & - & - & - & 0.01 & 0.01 & $10 / 22 / 2013$ \\
\hline Uganda & 0.53 & 0.53 & $11 / 26 / 2014$ & 1.33 & 1.33 & $11 / 26 / 2014$ \\
\hline Ukraine & 4.03 & 4.03 & $10 / 23 / 2012$ & 10.08 & 10.08 & $10 / 22 / 2013$ \\
\hline
\end{tabular}




\begin{tabular}{|c|c|c|c|c|c|c|}
\hline \multicolumn{7}{|c|}{$\begin{array}{l}\text { Appendix Table 5. Distribution of the General Reserve } \\
\text { Associated with Gold Windfall Profits (concluded) } \\
\text { (As of end-February 2018) }\end{array}$} \\
\hline \multirow{3}{*}{ Member } & \multicolumn{3}{|c|}{ Distribution of SDR 700 Million 3/ } & \multicolumn{3}{|c|}{ Distribution of SDR 1,750 Million 4/ } \\
\hline & Pledges & $\begin{array}{c}\text { Payment/Transfer } \\
\text { Amount } \\
\end{array}$ & \multirow{2}{*}{$\begin{array}{l}\text { Date of Transfer/Equivalent } \\
\text { Bilateral Contribution }\end{array}$} & Pledges & $\begin{array}{c}\text { Payment/Transfer } \\
\text { Amount } \\
\end{array}$ & \multirow[t]{2}{*}{$\begin{array}{l}\text { Date of Transfer/Equivalent } \\
\text { Bilateral Contribution }\end{array}$} \\
\hline & \multicolumn{2}{|c|}{ (In millions of SDRs) } & & \multicolumn{2}{|c|}{ (In millions of SDRs) } & \\
\hline United Kingdom 5/ & 31.57 & 32.21 & $3 / 21 / 2013$ & 78.92 & 78.83 & $4 / 7 / 2014$ \\
\hline United States & 123.83 & 123.83 & $10 / 23 / 2012$ & 309.57 & 309.57 & $10 / 22 / 2013$ \\
\hline Uruguay & 0.90 & 0.90 & $10 / 23 / 2012$ & 2.25 & 2.25 & $10 / 22 / 2013$ \\
\hline Uzbekistan & 0.81 & - & pending & - & - & - \\
\hline Vanuatu & - & - & - & 0.12 & 0.12 & $10 / 22 / 2013$ \\
\hline Venezuela & - & - & - & - & - & - \\
\hline Vietnam 6/ & 1.35 & 1.35 & $4 / 5 / 2013$ & 3.39 & 3.39 & 10/22/2013 \\
\hline Yemen, Republic of & - & - & - & 1.79 & 1.79 & $10 / 22 / 2013$ \\
\hline Zambia & 1.44 & 1.44 & 10/23/2012 & 3.59 & 3.59 & $10 / 22 / 2013$ \\
\hline Zimbabwe & 1.04 & 1.04 & 10/23/2012 & 2.60 & 2.60 & $10 / 22 / 2013$ \\
\hline Total & 664.6 & 623.5 & & $1,663.7$ & $1,563.9$ & \\
\hline Total in percent of distribution & 94.9 & 89.1 & & 95.1 & 89.4 & \\
\hline $\begin{array}{l}\text { 1/ Self-sustained PRGT fundrai } \\
\text { 2/ Madagascar was not approz } \\
\text { their arrears. } \\
\text { 3/ The distribution became eff } \\
\text { based on the quota shares in } \\
\text { on originally pledged amount, } \\
\text { 4/ The distribution became eff } \\
\text { based on the quota shares in } \\
\text { on originally pledged amount, } \\
\text { 5/ Member's actual contributi } \\
\text { 6/ The actual contribution incl } \\
\text { 7/ Switzerland pledged to con } \\
\text { January 24, } 2018 \text {. }\end{array}$ & $\begin{array}{l}\text { ing campa } \\
\text { hed with t } \\
\text { ctive on O } \\
\text { ace on the } \\
\text { vhere appl } \\
\text { ctive on O } \\
\text { ace on the } \\
\text { vhere appl } \\
\text { differs frc } \\
\text { des interes } \\
\text { ibute its st }\end{array}$ & $\begin{array}{l}\text { ign. } \\
\text { the request for con } \\
\text { ctober 12, } 2012 \text { an } \\
\text { day the distributic } \\
\text { icable. } \\
\text { ctober } 10,2013 \text { an } \\
\text { day the distributic } \\
\text { licable. } \\
\text { om initial pledge o } \\
\text { t earned in the Int } \\
\text { hares under both d }\end{array}$ & $\begin{array}{l}\text { tributing under either distribu } \\
\text { d was implemented on Octob } \\
\text { n was effected. Payments als } \\
\text { d was implemented on Octob } \\
\text { n was effected. Payments als } \\
\text { account of foreign exchang } \\
\text { erim Administered Account. } \\
\text { istributions in five equal annu }\end{array}$ & $\begin{array}{l}\text { ion; Sudar } \\
\text { 23, } 2012 \\
\text { include in } \\
\text { 22, } 2013 \\
\text { include in } \\
\text { rates on v } \\
\text { installme }\end{array}$ & $\begin{array}{l}\text { 's and Somalia's st } \\
\text { The amount distr } \\
\text { terest earned in In } \\
\text { The amount distr } \\
\text { terest earned in In } \\
\text { alue date of paym } \\
\text { nts. The last install }\end{array}$ & $\begin{array}{l}\text { ares were applied against } \\
\text { uted to members was } \\
\text { uted Administered Account } \\
\text { rim Administered Account } \\
\text { t. }\end{array}$ \\
\hline
\end{tabular}




\begin{tabular}{|c|c|c|c|c|c|c|c|c|}
\hline \multicolumn{9}{|c|}{$\begin{array}{l}\text { Appendix Table 6. PRGT_-Subsidy Agreements 1/ } \\
\text { (In millions of SDRs; as of end-February 2018) }\end{array}$} \\
\hline & \multirow{2}{*}{$\begin{array}{c}\text { Effective date of } \\
\text { agreement }\end{array}$} & \multirow[b]{2}{*}{ Vehicle 2/ } & \multicolumn{3}{|c|}{ Deposit/Investment Amount } & \multirow{2}{*}{$\begin{array}{c}\text { Interest Rate } \\
\text { (percent) }\end{array}$} & \multirow{2}{*}{\multicolumn{2}{|c|}{$\begin{array}{c}\begin{array}{c}\text { Maturity } \\
\text { (years) }\end{array} \\
\end{array}$}} \\
\hline & & & Agreed & Received & Outstanding & & & \\
\hline \multicolumn{9}{|l|}{ Austria } \\
\hline Austrian National Bank & Jun. 8,1988 & Admin. Account & 60.0 & 60.0 & -- & 0.5 & $51 / 2-10$ & $3 /$ \\
\hline Austrian National Bank & Apr. 19, 1994 & Admin. Account & 50.0 & 50.0 & -- & 0.5 & $51 / 2-10$ & $3 /$ \\
\hline \multicolumn{9}{|l|}{ Belgium } \\
\hline National Bank of Belgium & Jun. 30,1989 & Admin. Account & 100.0 & 100.0 & -- & 0.5 & 10 & $3 /$ \\
\hline National Bank of Belgium & Apr. 21, 1994 & Admin. Account & 80.0 & 80.0 & -- & 0.5 & 10 & $3 /$ \\
\hline \multicolumn{9}{|l|}{ Botswana } \\
\hline Bank of Botswana 4/ 5/ & Jun. 30, 1994 & Admin. Account & 6.9 & 6.9 & -- & 2.0 & 10 & $3 /$ \\
\hline Bank of Botswana 6/ 7/ & Aug. 22, 2012 & General Subsidy Account & 1.5 & 1.5 & 1.5 & 0.1 & $5+5$ & \\
\hline \multicolumn{9}{|l|}{ Chile } \\
\hline Banco Central de Chile & Aug. 24, 1994 & Admin. Account & 15.0 & 15.0 & -- & 0.5 & 5 & $3 /$ \\
\hline \multicolumn{9}{|l|}{ China } \\
\hline People's Bank of China 6/ 8/ & Aug. 23, 2011 & General Subsidy Account & 100.0 & 100.0 & 100.0 & 0.1 & $61 / 4$ plus & \\
\hline \multicolumn{9}{|l|}{ Greece } \\
\hline Bank of Greece & Nov. 30, 1988 & Admin. Account & 35.0 & 35.0 & -- & 0.5 & $51 / 2-10$ & $3 /$ \\
\hline Bank of Greece & Apr. 22, 1994 & Admin. Account & 35.0 & 35.0 & -- & 0.5 & $51 / 2-10$ & $3 /$ \\
\hline \multicolumn{9}{|l|}{ Indonesia } \\
\hline Bank Indonesia 9/ & Jun. 23, 1994 & Admin. Account & 25.0 & 25.0 & -- & -- & 10 & $3 /$ \\
\hline Bank Indonesia 10/ & Jun. 30, 2014 & General Subsidy Account & 25.0 & 25.0 & -- & Variable 7/ & $1 / 3$ & $3 /$ \\
\hline Bank Indonesia 11/ & Oct. 27, 2014 & General Subsidy Account & 25.0 & 25.0 & 25.0 & Variable 8/ & 4 & \\
\hline \multicolumn{9}{|l|}{ Iran, Islamic Republic of } \\
\hline Central Bank of Iran & May 24, 1994 & Admin. Account & 5.0 & 5.0 & -- & 0.5 & 10 & $3 /$ \\
\hline \multicolumn{9}{|l|}{ Malaysia } \\
\hline Bank Negara Malaysia & May 17,1988 & Subsidy Account & 40.0 & 40.0 & -- & 0.5 & 10 & $3 /$ \\
\hline Bank Negara Malaysia 5/ & Jun. 30,1994 & Subsidy Account & 40.0 & 40.0 & -- & 2.0 & 10 & $3 /$ \\
\hline \multicolumn{9}{|l|}{ Malta } \\
\hline Central Bank of Malta & Dec. 13, 1989 & Subsidy Account & 1.4 & 1.4 & -- & 0.5 & 13 & $3 /$ \\
\hline Central Bank of Malta & May 27, 1994 & PRGF-ESF Subsidy Account & 1.4 & 1.4 & -- & 0.5 & 13 & $3 /$ \\
\hline \multicolumn{9}{|l|}{ Morocco } \\
\hline Bank Al.-Maghrib 12/ & Mar. 22, 2012 & General Subsidy Account & 7.8 & 7.8 & 7.8 & -- & $5+0.5+5$ & \\
\hline \multicolumn{9}{|l|}{ Pakistan } \\
\hline State Bank of Pakistan 13/ & Apr. 21, 1994 & ECF Subsidy Account & 10.0 & 10.0 & -- & 0.5 & 16 & $3 /$ \\
\hline \multicolumn{9}{|l|}{ Peru } \\
\hline Banco Central de Reserva del Peru 6/ 14/ & Jan. 29, 2010 & General Subsidy Account & 6.1 & 6.1 & 6.1 & 0.1 & $7+7$ & \\
\hline Portugal & & & & & & & & \\
\hline Banco do Portugal & May 5, 1994 & Admin. Account & 13.1 & 13.1 & -- & 0.5 & $6-10$ & $3 /$ \\
\hline Saudi Arabia & & & & & & & & \\
\hline $\begin{array}{l}\text { The Saudi Fund for Development and the } \\
\text { Kingdom of Saudi Arabia 15/ }\end{array}$ & Apr. 11, 2006 & General Subsidy Account & 132.6 & 115.9 & 115.9 & 0.5 & $15 \frac{1}{2}$ & \\
\hline Singapore & & & & & & & & \\
\hline Monetary Authority of Singapore & Nov. 4, 1988 & Subsidy Account & 40.0 & 40.0 & -- & 2.0 & 10 & $3 /$ \\
\hline Monetary Authority of Singapore 5/ & May 20, 1994 & Subsidy Account & 40.0 & 40.0 & -- & 2.0 & 10 & $3 /$ \\
\hline Spain & & & & & & & & \\
\hline Government of Spain 16/ & Feb. 8, 1995 & General Subsidy Account & 60.3 & 60.3 & -- & 0.5 & 10 & $3 /$ \\
\hline Thailand & & & & & & & & \\
\hline Bank of Thailand & Jun. 14,1988 & Subsidy Account & 20.0 & 20.0 & -- & 2.0 & 10 & $3 /$ \\
\hline Bank of Thailand & Apr. 22, 1994 & Subsidy Account & 40.0 & 40.0 & -- & 2.0 & 10 & $3 /$ \\
\hline Trinidad and Tobago & & & & & & & & \\
\hline Government of Trinidad and Tobago & Dec. 7, 2006 & ECF Subsidy Account & 3.0 & 3.0 & 3.0 & 1.0 & 10 & $3 /$ \\
\hline
\end{tabular}




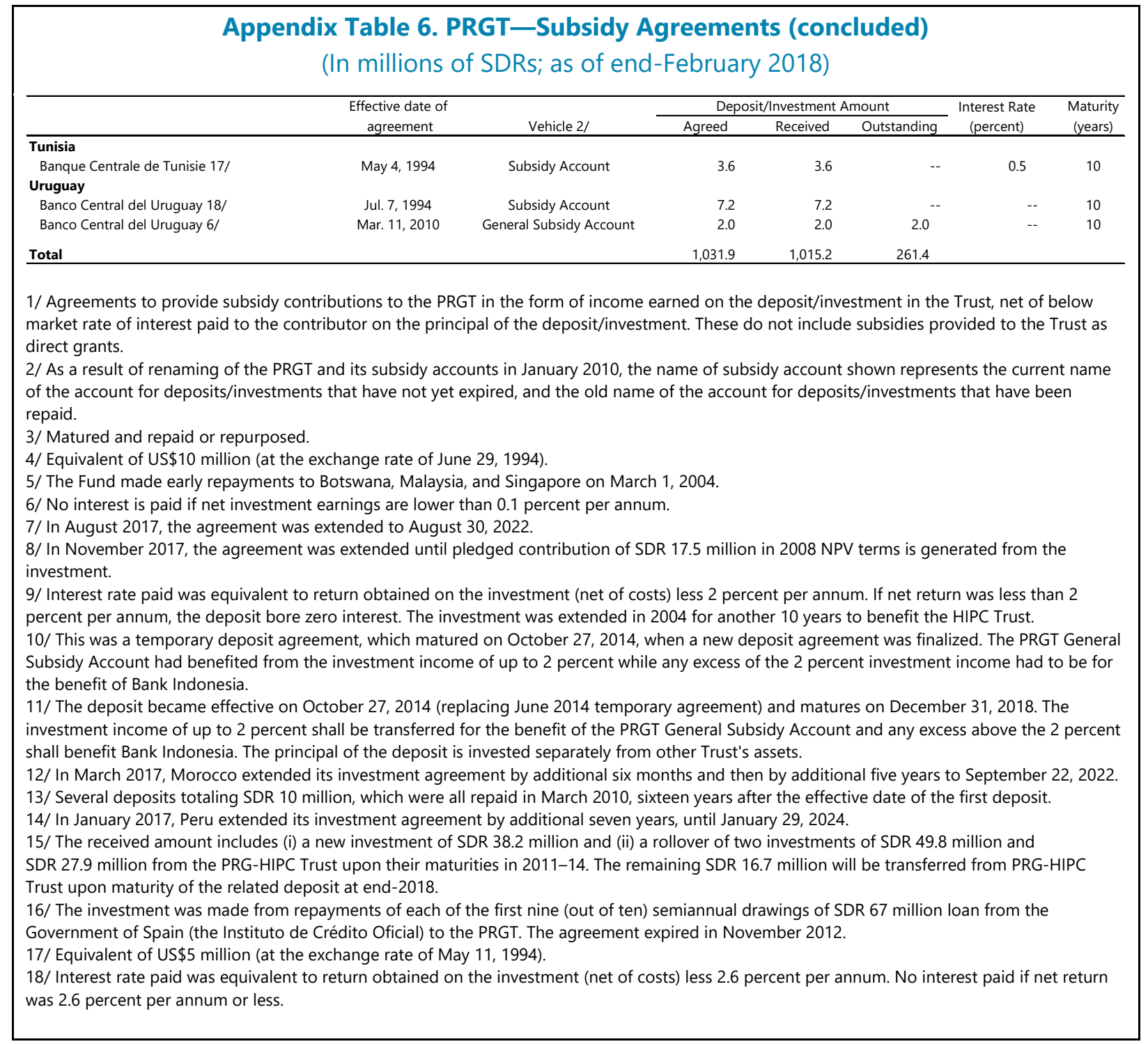

\section{CInternational Monetary Fund. Not for Redistribution}




\begin{tabular}{|c|c|c|c|c|c|c|}
\hline \multicolumn{7}{|c|}{$\begin{array}{l}\text { Appendix Table 7. PRG-HIPC Trust-Bilateral Deposit/Investment Agreements } \\
\text { (In SDRs; as of end-February 2018) }\end{array}$} \\
\hline Contributor & Type of agreement & $\begin{array}{l}\text { Effective date } \\
\text { of agreement }\end{array}$ & Amount & $\begin{array}{l}\text { Amount } \\
\text { outstanding }\end{array}$ & $\begin{array}{l}\text { Interest rate } \\
\text { (per annum) }\end{array}$ & $\begin{array}{l}\text { Term/date } \\
\text { of maturity } 1 /\end{array}$ \\
\hline Algeria & Deposit Agreement & $3 / 27 / 2001$ & $7,600,000$ & $7,600,000$ & $0 \%$ & 20 years \\
\hline Argentina & Deposit Agreement & $5 / 4 / 2001$ & $15,628,059$ & $15,628,059$ & $0 \%$ & 19 years \\
\hline Botswana & Investment Agreement & $4 / 25 / 1997$ & $14,607,060$ & - & $2 \%$ & $4 / 30 / 20022 /$ \\
\hline Botswana & Investment Agreement & $8 / 9 / 2002$ & $15,065,760$ & - & $1 \%$, variable $3 /$ & 5 years $2 /$ \\
\hline Botswana & Investment Agreement & $5 / 9 / 2008$ & $6,142,590$ & - & $1 \%$, variable $3 /$ & 5 years $2 /$ \\
\hline Brunei Darussalam & Deposit Agreement & 10/24/2001 & 52,351 & 52,351 & $0 \%$ & $12 / 31 / 2018$ \\
\hline Chile & Deposit Agreement & 10/1/1999 & $15,000,000$ & - & $0.5 \%$ & 5 years $2 /$ \\
\hline Colombia & Deposit Agreement & $9 / 21 / 2001$ & $1,181,774$ & $1,181,774$ & $0 \%$ & $12 / 31 / 2018$ \\
\hline Croatia & Deposit Agreement & $4 / 9 / 2001$ & 519,161 & 519,161 & $0 \%$ & $12 / 31 / 2018$ \\
\hline Czech Republic & Deposit Agreement & $2 / 22 / 2000$ & $5,664,038$ & $5,664,038$ & $0 \%$ & 20 years \\
\hline Egypt & Deposit Agreement & $6 / 16 / 2000$ & $1,723,680$ & $1,723,680$ & $0 \%$ & $12 / 31 / 2018$ \\
\hline Fiji & Deposit Agreement & $8 / 28 / 2003$ & 194,021 & 194,021 & $0 \%$ & $12 / 31 / 2018$ \\
\hline Finland & Deposit Agreement & $2 / 22 / 2001$ & $5,811,869$ & $5,811,869$ & $0 \%$ & $12 / 31 / 2018$ \\
\hline Germany & Deposit Agreement & $1 / 31 / 2000$ & $220,656,3004 /$ & - & $0 \%$ & 10 years $2 /$ \\
\hline Ghana & Deposit Agreement & $5 / 10 / 2000$ & 982,328 & - & $0.5 \%$ & 10 years $2 /$ \\
\hline Greece & Deposit Agreement & $2 / 22 / 2001$ & $5,440,000$ & - & $0 \%$ & 10 years $2 /$ \\
\hline Hungary & Deposit Agreement & $12 / 8 / 2000$ & $9,237,105$ & $9,237,105$ & $0 \%$ & $12 / 9 / 2018$ \\
\hline India & Deposit Agreement & $3 / 31 / 2000$ & $31,370,304$ & $31,370,304$ & $0 \%$ & $12 / 31 / 2018$ \\
\hline Indonesia & Deposit Agreement & $7 / 18 / 2000$ & $4,850,030$ & $4,850,030$ & $0 \%$ & $12 / 31 / 2018$ \\
\hline Indonesia & $\begin{array}{l}\text { The Instrument for the } \\
\text { Administered Account Indonesia }\end{array}$ & $6 / 30 / 2004$ & $25,000,000$ & - & Variable 5/ & June, 2014 2/ \\
\hline Iran, Islamic Republic of & Investment Agreement & $5 / 30 / 1997$ & $5,000,0006 /$ & - & $0.5 \%$ & 10 years $2 /$ \\
\hline Kuwait & Deposit Agreement & $7 / 25 / 2000$ & $4,196,595$ & $4,196,595$ & $0 \%$ & $12 / 31 / 2018$ \\
\hline Libya & Deposit Agreement & $10 / 8 / 2002$ & $9,950,370$ & $9,950,370$ & $0 \%$ & $12 / 31 / 2019$ \\
\hline Malaysia & Investment Agreement & 6/26/1998 & $20,000,000$ & - & $0.5 \%$, variable $7 /$ & 10 years $2 /$ \\
\hline Malaysia & Deposit Agreement & $5 / 29 / 2001$ & $7,368,106$ & $7,368,106$ & $0 \%$ & $12 / 31 / 2018$ \\
\hline Morocco & Deposit Agreement & $6 / 22 / 2000$ & $2,186,968$ & $2,186,968$ & $0 \%$ & 20 years \\
\hline Oman & Deposit Agreement & $7 / 5 / 2001$ & $1,057,041$ & $1,057,041$ & $0 \%$ & $12 / 31 / 2018$ \\
\hline Pakistan & Deposit Agreement & $6 / 22 / 2000$ & $4,659,307$ & $4,659,307$ & $0 \%$ & 20 years \\
\hline Paraguay & Deposit Agreement & 12/18/2001 & 310,097 & - & $1 \%$ & 5 years $2 /$ \\
\hline Peru & Deposit Agreement & $1 / 28 / 2000$ & $6,143,881$ & - & $1.5 \%$ & 10 years $2 /$ \\
\hline Poland & Deposit Agreement & $6 / 12 / 2000$ & $7,073,780$ & $7,073,780$ & $0 \%$ & 20 years \\
\hline Qatar & Deposit Agreement & $5 / 25 / 2000$ & 749,713 & 749,713 & $0 \%$ & $12 / 31 / 2018$ \\
\hline
\end{tabular}




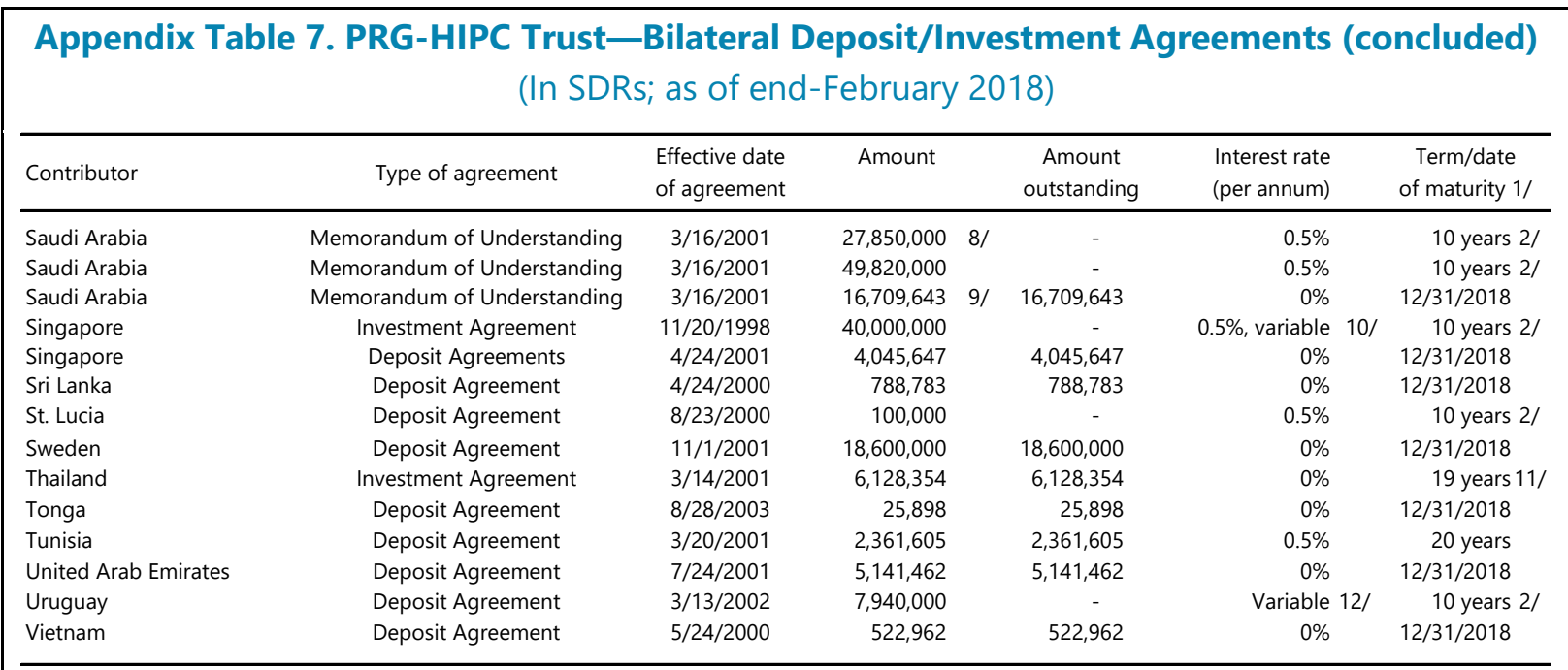

1 / Some agreements specify the maturity date, while some state a term; a "10 years" term indicates that the deposit is due in 10 years from the effective date of the agreement.

2/ Matured and repaid or repurposed.

3/ Original interest rate was $2 \%$ per annum; in August 2004, the rate was amended to $1 \%$ per annum, but could have been reverted to $2 \%$ per annum if the return on investment reached $3 \%$ per annum.

4/ The agreement amount was Euro 300 million.

$5 / 2 \%$ per annum of the net investment earnings (or any lesser amount if the returns on investments was below $2 \%$ ) was to be transferred to the PRGF-HIPC Trust and the remainder to the depositor. Upon maturity of the deposit in June 2014, the Indonesian authorities agreed to put the SDR 25 million principal in a temporary deposit, pending an agreement to reinvest it to benefit the PRGT.

6/ Five annual installments, each equivalent to SDR 1 million, of 10 year maturity.

7/ Two installments (received in June 1998 and August 1999) with maturity date of 10 years each. Original interest rate of $2 \%$ per annum was amended in June 2004 to $0.5 \%$ per annum, with an option to be reverted to $2 \%$ per annum if the return on investment reached $2 \%$ per annum. 8/ This investment consisted of 14 installments, each of 10 year maturity, with the first one received on March 27, 2001 and the last one on September 27, 2004. The installments originated from repayments of the outstanding amounts of loans made by the SFD to PRGF borrowers and the date of each installment corresponded to the date of repayment of the associated loans. Upon maturity, each subsequent installment has been reinvested to benefit the PRGT.

9/ Committed to be transferred upon maturity to the PRGT as an investment, and to become a grant on December 31, 2021.

10/ Four annual installments of SDR 10 pmillions each (received in November 1998, August 1999, August 2000, and August 2001, respectively) and 10 year maturity. Original interest rate of $2 \%$ per annum was amended in August 2004 to $0.5 \%$ per annum, with an option to revert to $2 \%$ per annum if the return on investment reached $2 \%$ per annum.

11 / Maturity of 19 years or at the end of life of the Trust, whichever is earlier.

12 / Interest rate obtained by the Trust minus $2.6 \%$ per annum; if the interest rate was $2.6 \%$ per annum or less, no interest was paid to the depositor. 


\begin{tabular}{|c|c|c|c|}
\hline \multicolumn{4}{|c|}{$\begin{array}{c}\text { Appendix Table 8. Pending Bilateral Contributions of Subsidy Resources } \\
\text { to the PRGT and PRG-HIPC Trust } \\
\text { (In millions of SDRs; as of end-February 2018) }\end{array}$} \\
\hline \multirow[t]{2}{*}{ Country } & \multirow[t]{2}{*}{ Contribution pledged } & \multicolumn{2}{|c|}{ Of which } \\
\hline & & Amount received & Amount pending \\
\hline \multicolumn{4}{|c|}{ Under the HIPC Initiative fundraising round 1/ } \\
\hline Bahrain & 0.90 & - & 0.90 \\
\hline Dominican Republic & 0.50 & - & 0.50 \\
\hline Gabon & 2.50 & 0.60 & 1.90 \\
\hline Grenada & 0.10 & - & 0.10 \\
\hline Lebanon & 0.40 & - & 0.40 \\
\hline Maldives & 0.01 & - & 0.01 \\
\hline Trinidad \& Tobago & 1.62 & - & 1.62 \\
\hline Vanuatu & 0.10 & - & 0.10 \\
\hline Venezuela & 20.35 & - & 20.35 \\
\hline Subtotal & 26.48 & 0.60 & 25.88 \\
\hline \multicolumn{4}{|c|}{ Under the ESF fundraising round } \\
\hline Oman & 3.00 & 2.20 & 0.80 \\
\hline Trinidad and Tobago & 0.80 & 0.17 & 0.63 \\
\hline Subtotal & 3.80 & 2.37 & 1.43 \\
\hline \multicolumn{4}{|c|}{ Under the 2009 fundraising round } \\
\hline Saudi Arabia & 16.70 & - & $16.702 /$ \\
\hline South Africa & 3.40 & - & 3.40 \\
\hline Trinidad and Tobago & 0.60 & - & 0.60 \\
\hline Subtotal & 20.70 & - & 20.70 \\
\hline \multicolumn{4}{|c|}{ Under the first distribution of the general reserve associated with gold windfall profits (of SDR 700 million) } \\
\hline Brazil & 12.50 & - & 12.50 \\
\hline Costa Rica & 0.48 & - & 0.48 \\
\hline Grenada & 0.03 & - & 0.03 \\
\hline Hungary & 3.05 & - & 3.05 \\
\hline Indonesia & 6.11 & - & 6.11 \\
\hline Lebanon & 0.78 & - & 0.78 \\
\hline Libya & 3.30 & - & 3.30 \\
\hline Peru & 1.88 & - & 1.88 \\
\hline Poland & 4.96 & - & 4.96 \\
\hline Uzbekistan & 0.81 & - & 0.81 \\
\hline Subtotal & 33.91 & - & 33.91 \\
\hline \multicolumn{4}{|c|}{ Under the second distribution of the general reserve associated with gold windfall profits (of SDR 1,750 million) } \\
\hline Azerbaijan & 1.18 & - & 1.18 \\
\hline Bahrain & 0.99 & - & 0.99 \\
\hline Brazil & 31.24 & - & 31.24 \\
\hline Colombia & 5.57 & - & 5.57 \\
\hline Costa Rica & 1.21 & - & 1.21 \\
\hline Equatorial Guinea & 0.38 & - & 0.38 \\
\hline Ghana & 2.71 & - & 2.71 \\
\hline Hungary & 7.63 & - & 7.63 \\
\hline Indonesia & 15.28 & - & 15.28 \\
\hline Lebanon & 1.96 & - & 1.96 \\
\hline Libya & 8.26 & - & 8.26 \\
\hline Papua New Guinea & 0.97 & - & 0.97 \\
\hline Peru & 4.69 & - & 4.69 \\
\hline Poland & 12.41 & - & 12.41 \\
\hline Qatar & 2.22 & - & 2.22 \\
\hline Subtotal & 96.71 & - & 96.71 \\
\hline Total & 181.61 & 2.97 & 178.63 \\
\hline $\begin{array}{l}\text { Estimated on "as neec } \\
\text { To be provided at enc }\end{array}$ & of Saudi Arabia investme & the benefit of HIPC & PRGT. \\
\hline
\end{tabular}




\begin{tabular}{|c|c|c|c|}
\hline \multicolumn{4}{|c|}{$\begin{array}{l}\text { Appendix Table 9. PRGT Reserve Account Coverage } \\
\text { (In millions of SDRs; end-period) }\end{array}$} \\
\hline Year & $\begin{array}{c}\text { Reserve Account } \\
\text { balance } \\
\text { (A) }\end{array}$ & $\begin{array}{l}\text { Outstanding } \\
\text { PRGT credit 3/ } \\
\text { (B) } \\
\end{array}$ & $\begin{array}{c}\text { Reserve coverage } \\
\text { ratio (In percent) } \\
(\mathrm{A}) /(\mathrm{B})\end{array}$ \\
\hline 1988 & 169 & 103 & 164.1 \\
\hline 1989 & 272 & 510 & 53.3 \\
\hline 1990 & 395 & 795 & 49.7 \\
\hline 1991 & 513 & 1,320 & 38.9 \\
\hline 1992 & 630 & 1,786 & 35.3 \\
\hline 1993 & 793 & 2,005 & 39.6 \\
\hline 1994 & 1,009 & 2,786 & 36.2 \\
\hline 1995 & 1,336 & 3,919 & 34.1 \\
\hline 1996 & 1,716 & 4,446 & 38.6 \\
\hline 1997 & 2,093 & 4,892 & 42.8 \\
\hline 1998 & 2,345 & 5,421 & 43.3 \\
\hline 1999 & 2,548 & 5,820 & 43.8 \\
\hline 2000 & 2,714 & 5,773 & 47.0 \\
\hline 2001 & 2,917 & 5,971 & 48.9 \\
\hline 2002 & 3,079 & 6,636 & 46.4 \\
\hline 2003 & 3,115 & 6,703 & 46.5 \\
\hline 2004 & 3,174 & 6,632 & 47.9 \\
\hline 2005 & 3,285 & 6,185 & 53.1 \\
\hline 2006 & 3,392 & $3,6561 /$ & 92.8 \\
\hline 2007 & 3,557 & 3,673 & 96.8 \\
\hline 2008 & 3,818 & 3,895 & 98.0 \\
\hline 2009 & 3,926 & 4,965 & 79.1 \\
\hline 2010 & 3,967 & 5,068 & 78.3 \\
\hline 2011 & 3,981 & 5,092 & 78.2 \\
\hline 2012 & $3,962 \quad 2 /$ & 5,581 & 71.0 \\
\hline 2013 & $3,919 \quad 2 /$ & 5,972 & 65.6 \\
\hline 2014 & $3,861 \quad 2 /$ & 6,063 & 63.7 \\
\hline 2015 & $3,826 \quad 2 /$ & 6,398 & 59.8 \\
\hline 2016 & 3,880 & 6,380 & 60.8 \\
\hline 2017 & $3,816 \quad 2 /$ & 6,434 & 59.3 \\
\hline \multicolumn{4}{|c|}{ Memorandum item: } \\
\hline $\begin{array}{l}\text { 1/ The decline in total PRGT credit } \\
\text { MDRI debt relief. } \\
2 / \text { The decline in Reserve Account b } \\
\text { have exceeded net investment retur } \\
3 \text { / Credit outstanding to PRGT lend }\end{array}$ & $\begin{array}{l}\text { anding by about } 40 \text { percen } \\
\text { ces during } 2012-15 \text { and in }\end{array}$ & $\begin{array}{l}\text { from } 2005 \text { reflects early } \\
017 \text { is on account of the }\end{array}$ & $\begin{array}{l}\text { ayments arising from the } d \\
\text { ministrative fees reimbursec }\end{array}$ \\
\hline
\end{tabular}




\begin{tabular}{|c|c|c|c|c|}
\hline & MDRI-II Transfer & Pledged & Received & $\begin{array}{c}\text { Total contributions } \\
\text { received }\end{array}$ \\
\hline & In SDR million & In US\$ million & SDR equivalent & SDR equivalent \\
\hline Argentina & 0.40 & - & - & 0.40 \\
\hline Australia & 0.13 & - & - & 0.13 \\
\hline Austria 1/ & - & - & - & - \\
\hline Bangladesh & 0.01 & - & - & 0.01 \\
\hline Belgium & 1.37 & - & - & 1.37 \\
\hline Botswana & 0.02 & - & - & 0.02 \\
\hline Canada & 2.94 & - & - & 2.94 \\
\hline Chile & 0.05 & - & - & 0.05 \\
\hline China & 0.15 & - & - & 0.15 \\
\hline Denmark & 0.82 & - & - & 0.82 \\
\hline Egypt & 0.15 & - & - & 0.15 \\
\hline Finland & 0.53 & - & - & 0.53 \\
\hline France & 4.04 & - & - & 4.04 \\
\hline Germany & 2.29 & 30.00 & 21.49 & 23.79 \\
\hline Greece & 0.46 & - & - & 0.46 \\
\hline Iceland & 0.05 & - & - & 0.05 \\
\hline Indonesia & 0.07 & - & - & 0.07 \\
\hline Ireland & 0.08 & - & - & 0.08 \\
\hline Italy & 2.93 & - & - & 2.93 \\
\hline Japan & 8.80 & 7.30 & 5.34 & 14.14 \\
\hline Korea & 0.73 & - & - & 0.73 \\
\hline Malaysia & 0.39 & - & - & 0.39 \\
\hline Malta & 0.02 & - & - & 0.02 \\
\hline Mexico & - & 11.00 & - & - \\
\hline Morocco & 0.11 & - & - & 0.11 \\
\hline Norway & 0.54 & - & - & 0.54 \\
\hline Pakistan & 0.01 & - & - & 0.01 \\
\hline Portugal & 0.05 & 2.00 & 1.45 & 1.50 \\
\hline Saudi Arabia & 0.19 & - & - & 0.19 \\
\hline Singapore & 0.22 & - & - & 0.22 \\
\hline Spain & 0.11 & - & - & 0.11 \\
\hline Sweden & 2.26 & - & - & 2.26 \\
\hline Switzerland & 1.34 & - & - & 1.34 \\
\hline Thailand & 0.15 & - & - & 0.15 \\
\hline Tunisia & 0.01 & - & - & 0.01 \\
\hline Turkey & - & 1.00 & 0.74 & 0.74 \\
\hline United Kingdom & 5.40 & 42.00 & 29.92 & 35.32 \\
\hline United States & 2.02 & - & - & 2.02 \\
\hline Uruguay & 0.02 & - & - & 0.02 \\
\hline Total & 38.86 & 93.30 & 58.94 & 97.81 \\
\hline
\end{tabular}




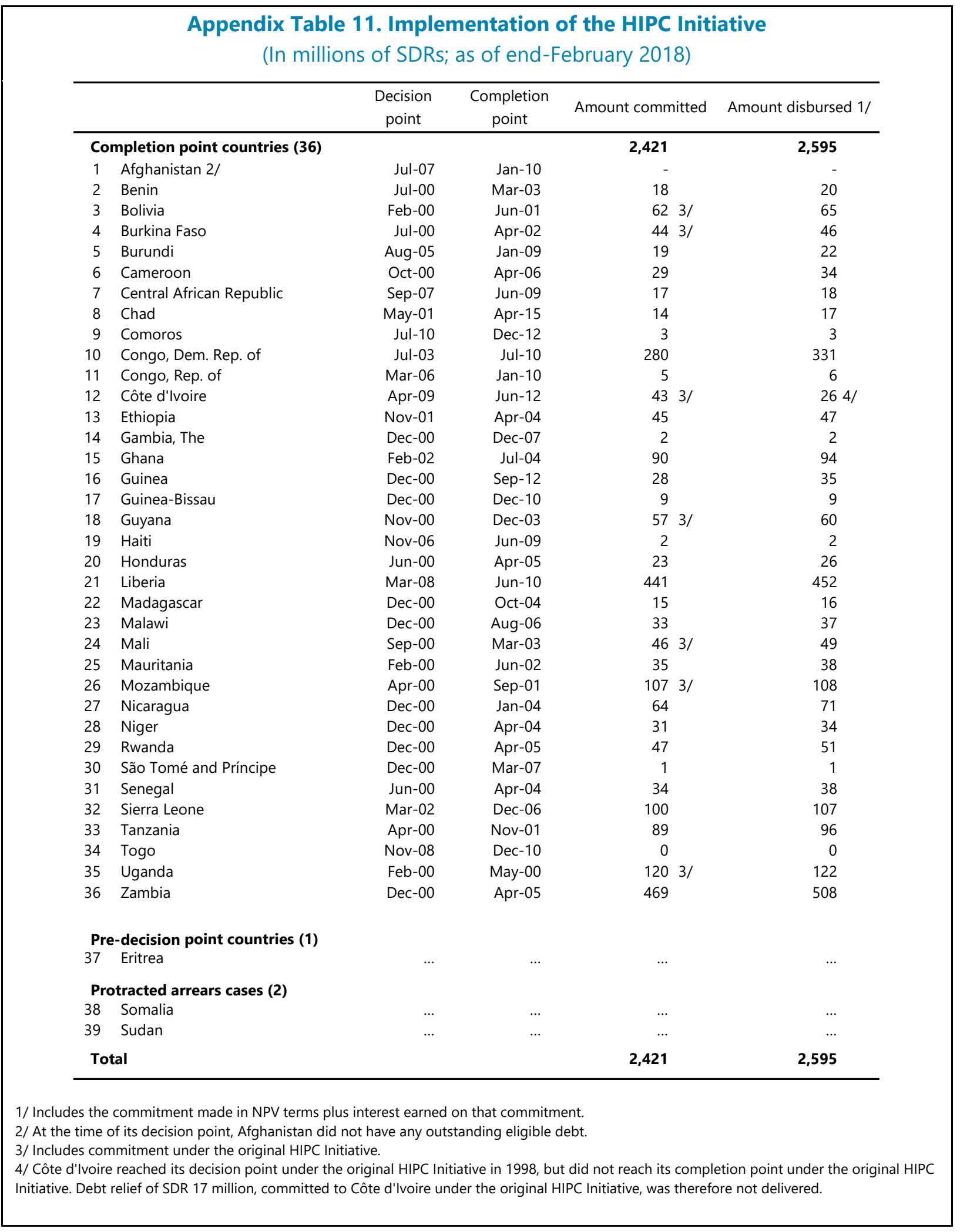




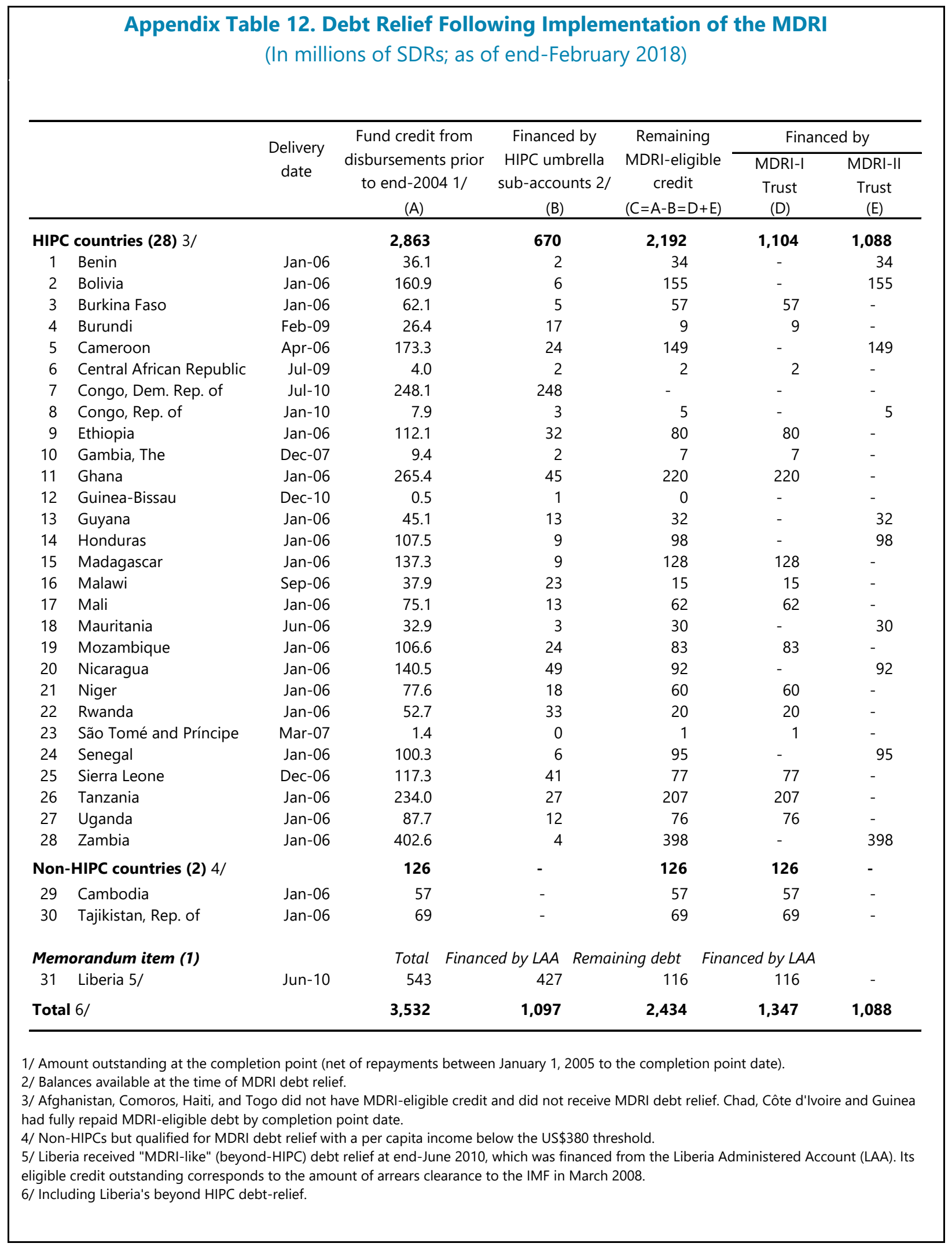

